\title{
Geochemistry and petrology of the Upper Silurian greywackes from the Holy Cross Mountains (central Poland): implications for the Caledonian history of the southern part of the Trans-European Suture Zone (TESZ)
}

\author{
Wojciech KOZŁOWSKI ${ }^{1, *}$, Justyna DOMAŃSKA-SIUDA ${ }^{1}$ and Jerzy NAWROCKI ${ }^{2}$ \\ 1 Faculty of Geology, University of Warsaw, Żwirki i Wigury 93, 02-089 Warszawa, Poland \\ 2 Polish Geological Institute - National Research Institute, Rakowiecka 4, 00-975 Warszawa, Poland
}

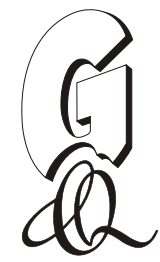

\begin{abstract}
Kozłowski, W., Domańska-Siuda, J., Nawrocki J., 2014. Geochemistry and petrology of the Upper Silurian greywackes from the Holy Cross Mountains (central Poland): implications for the Caledonian history of the southern part of the Trans-European Suture Zone (TESZ). Geological Quarterly, 58 (2): 311-336, doi: 10.7306/gq.1160

The Ludlovian greywackes of the Holy Cross Mountains (HCM) represent a part of the sedimentary cover of the Łysogóry and Małopolska terranes located in the Trans-European Suture Zone, central Poland. The rocks form the sedimentary infill of the Caledonian foreland basin that developed at the Tornquist margin of Laurussia and had source-areas located on the orogen side of the basin. Until the present, the source terrane of the basin has not been identified in its potential location - at the south-west margin of the East European Platform. The Ludlovian greywackes of both parts of the HCM show a lot of similarities in clast spectrum, timing, and geochemical features, which implies similar sources of the clastic material. The petrographic modal composition and geochemical features indicate recycled orogen signatures with a distinct undissected, evolved magmatic arc component. The latter is particularly evident from the extraclast spectrum that contains andesite, trachyte and dacite clasts. Beside the volcanic rocks, the source area consisted of sedimentary and metasedimentary rocks with high amounts of cherts. The geochemical and petrological features in the rock succession point to an evolution of the tectonic setting from an active to a more passive margin type indicating synorogenic formation of the studied rocks. Based on the rock record, we suggest that the Upper Silurian greywackes originated as a result of the collision of the Tornquist margin of Laurussia with a volcanic arc (here: the Teisseyre Arc) - located probably at the easternmost extent of the Avalonian Plate. In this scenario, the arc-continent orogen was composed of an uplifted filling of the forearc basin, an accretionary prism, volcanic arc rocks, and an exhumed foreland basement - analogously to the present-day Taiwan orogen. The second key issue is the palaeogeographical relation between the Małopolska (Kielce Region) and the Łysogóry terranes in the Late Silurian. Despite the analogous grain composition and clast types, the Łysogóry Region greywackes are composed of distinctly more altered detritus, which is in accordance with the more distal character of the Łysogóry Basin. The latter is manifested, e.g., in the lack of Caledonian deformations. The present-day adjacency of both domains containing correlative greywacke formations coupled with contrasting alteration and Late Silurian transport directions parallel to the terrane boundary imply small to medium-scale (below palaeomagnetic resolution) left-lateral movements of the Małopolska and Łysogóry crustal blocks along the Holy Cross Fault in post-Silurian times.
\end{abstract}

Key words: greywackes, provenance, arc-continent collision, foreland, Silurian, Holy Cross Mountains.

\section{INTRODUCTION}

The Trans-European Suture Zone (TESZ) crosses Poland from the north-west to the south-east and separates the East European Platform (EEP) and the West European Variscan mobile belt. The belt was formed during a multistage accretion and shuffling of terranes at the south-west margin of Baltica and later of Laurussia (Pharaoh, 1999; Belka et al., 2002; Winchester et al., 2002, 2006; Nawrocki and Poprawa, 2006; Oczlon et al., 2007). The Łysogóry and Małopolska terranes, lo-

\footnotetext{
* Corresponding author, e-mail: woko@uw.edu.pl
}

Received: April 30, 2013; accepted: February 10, 2014; first published online: March 31, 2014 cated in southeastern Poland, represent a part proximal to the EEP. The consolidation time of the crystalline basements of both terranes has not been recognized. Although the relation of these terranes to Baltica during the Proterozoic-Cambrian time is still a subject of debate (Belka et al., 2002; cf. Żelaźniewicz et al., 2009; see also Oczlon et al., 2007 and the discussion therein), its Silurian successions record a common development of the Caledonian foreland basin, referred to the Fennosarmatian sector of the Laurussian shelf (Jaworowski, 1971; Poprawa et al., 1999; Katzung, 2001; Kozłowski, 2003; Nawrocki and Poprawa, 2006; Nawrocki et al., 2007; Kozłowski, 2008; Fig. 1A).

The Silurian facies-tectonic evolution of the Łysogóry terrane is almost identical as in the marginal part of the EEP (Tomczyk, 1987; Dadlez, 2001; Narkiewicz, 2002; Kozłowski, 2008). In the case of the Małopolska terrane, despite the corresponding Silurian facies succession, there are several dissimilarities in relation to the adjacent Łysogóry terrane (see below). 


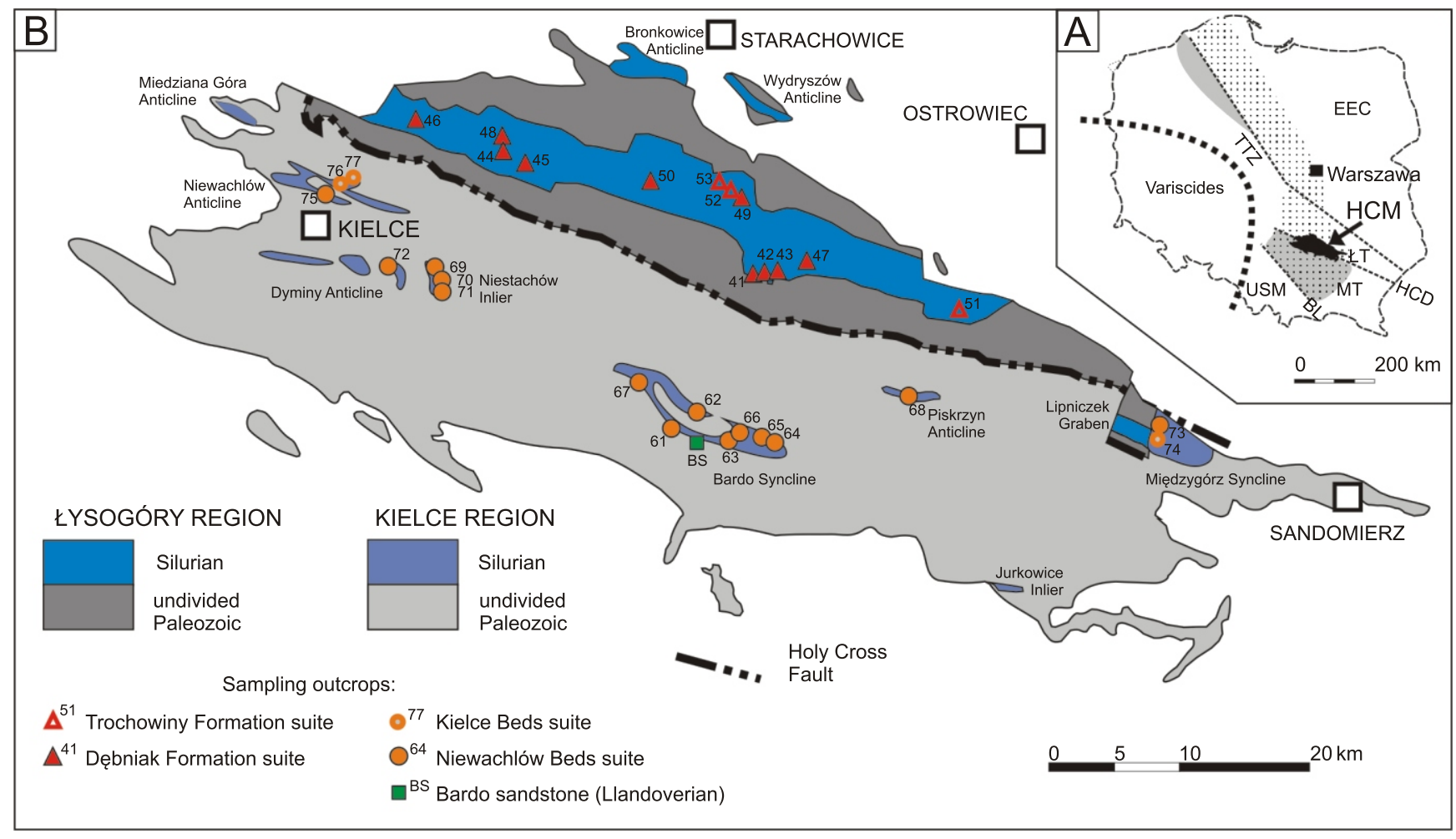

Fig. 1A - distribution of Upper Silurian greywacke-siltstone facies in Poland (dotted area after Jaworowski, 1971) and location of the Holy Cross Mountains (HCM); B - distribution of Silurian rocks in the Holy Cross Mountains area with location of the sampling outcrops (outcrop numbers compatible with the appendices and subsequent figures)

Shaded areas are regions with the presence of Caledonian deformations; BL - Krakow-Myszków Fault, HCD - Holy Cross Fault, $Ł T$ - Łysogóry terrane, MT - Małopolska terrane, USM - Upper Silesian Massif

The observed differences imply a possibility of post-Silurian, small-scale displacement of Małopolska along the Holy Cross Fault (e.g., Brochwicz-Lewiński et al., 1984; Narkiewicz, 2002; Kozłowski, 2008).

Based on the Silurian facies pattern (Jaworowski, 1971) and the transport directions (Kozłowski et al., 2004), the southern part of the Tornquist branch of the Caledonian orogen was located to the south-west of the Łysogóry and Małopolska terranes. The Caledonian hinterland has not been recognized, but the thick foreland successions of both blocks indicate its presence in the Silurian palaeogeography (Kozłowski, 2008). Because of the lack of the collision zone itself, the Caledonian history of the southern part of the TESZ may only be reconstructed based on the sedimentary and tectonic record of the foreland area.

The Silurian of the Łysogóry and Małopolska terranes is exposed in only one outcrop area - the Holy Cross Mountains (HCM) in central Poland. The Paleozoic inlier of the HCM is divided by the Holy Cross Fault into two tectono-facies domains (Czarnocki, 1936, 1950; Fig. 1B). The southern Kielce Region represents the northern margin of the Małopolska terrane, whereas the area to the north of the fault represents the southern part of the Łysogóry terrane. The Caledonian foreland basin infill, present in both HCM areas, is developed as a thick litharenite-mudstone complex commonly referred to as the Niewachlów (Kielce Region) and Wydryszów (Łysogóry Region) greywackes (Czarnocki, 1919). Because of the high content of volcaniclastic material in the greywackes, many authors stated a significant contribution of a fresh volcanic source in the formation of the deposits. However, the type and the palaeogeographical context of this volcanic activity were differently interpreted. The following ideas have been proposed:
- local volcanic sources - intraplate volcanism (Przybyłowicz and Stupnicka, 1991);

- active volcanic sources lying in adjacency in the Silurian and preserved until the present - e.g., Gemeric Zone of Slovakia (Kowalczewski, 1974; Romanek and Rup, 1989);

- axial part of the Caledonian geosyncline (Znosko, 1974);

- a volcanic arc located beyond the SW margin of the Małopolska terrane - probably incorporated in the present-day Variscan orogen - the Sudetes (Malec, 2001);

- an arc-continent Caledonian orogen located beyond the SW margin of the Małopolska terrane (Kozłowski et al., 2004).

These hypotheses are often supported by valuable data and observations (e.g., Romanek and Rup, 1989; Malec, 2001), but, unfortunately, they lack proper provenance studies.

The purpose of this study was to characterise in detail the provenance of the Ludlovian greywackes from both facies regions of the Holy Cross Mountains. The data were collected in 2001-2003 and the preliminary results of the research were published as an extended abstract in 2004 (Kozłowski et al., 2004). The present study, using subsequent detailed database analysis, tested two main hypotheses outlined in the initial phase of the research. The first of them is the derivation of the greywacke detritus from a single, arc-continent orogen source. The second is that the contrast in the alteration, observed between the greywackes of both regions, did not support the present-day adjacency of the Kielce and Łysogóry regions (Kozłowski et al., 2004). The final discussion of the current research is also devoted to the palaeogeographical significance of the Silurian 
greywackes from the HCM and the configuration of the particular terranes at the margin of the EEP in Silurian times.

\section{GEOLOGICAL SETTING}

The Ordovician-Silurian succession in the Kielce Region of the HCM inlier (Fig. 2) unconformably overlies Cambrian rocks deformed by the Sandomirian orogeny (Samsonowicz, 1934). The relatively thin Ordovician (up to $100 \mathrm{~m}$ ) is covered by up to $300 \mathrm{~m}$ thick complex of graptolitic shales belonging to the Llandoverian, Wenlockian and Gorstian. The very thin (up to 30 metres) Llandoverian radiolarites and siliceous shales indicate initially very low clastic input (e.g., Masiak et al., 2003). Only in the middle Llandoverian (upper part of the cyphus Zone), a single, $0.5 \mathrm{~m}$ thick intercalation of quartz arenite (Bardo sandstone) occurs. The Wenlockian-Gorstian part of the shale succession is composed of clayey shales with some carbonaceous-rich levels. The Upper Ordovician to Lower Silurian succession contains numerous bentonite layers (Ryka and Tomczyk, 1959; Tomczyk, 1970; Langier-Kuźniarowa and Ryka, 1972; Chlebowski, 1978), which increase upwards in number and thickness.

The first greywacke intercalation in the Kielce Region occurs at the base of the Saetograptus leintwardinensis Zone (Tomczyk, 1956). The following Niewachlów Beds (Czarnocki, 1919) are composed of lithic arenites, wackes, mudstones and fine-grained conglomerates. The often observed graded bedding indicates a deposition by turbiditic currents (Kozłowski and Tomczykowa, 1999; Malec, 2001). The mudstone-shale interbeds contain rare graptholites (Bohemograptus bohemicus; Tomczyk, 1970) indicating an early Ludfordian age of the greywackes. Because of the tectonic deformation and presence of the angular unconformity above, the total thickness of the Niewachlów Beds is difficult to estimate. The traceable continuous thickness of the formation in the Bardo Syncline and Niestachów Inlier is around 300 m (Kozłowski, 2008).

Locally, i.e., mostly in the axial part of anticlines, the Niewachlów Beds are succeeded by clayey shales intercalated with sublithic and quartz arenites, referred to the Kielce Beds (Malec, 2001). The total thickness of the Kielce Beds is likewise difficult to estimate, however, it is not less than $400 \mathrm{~m}$ (see discussion in Kozłowski, 2008). The redeposited benthic Ludfordian fauna occurs in the Niewachlów and Kielce Beds and shows distinct Laurussian [Baltic (Baliozoma erraticum Shrank)], Avalonian [Dalmanites nexilis (Salter)] and Laurentian (Helokybe cf. spio Thomas) affinities (Tomczykowa, 1993).

Flute marks and cross-bedding in the Niewachlów and Kielce Beds (Fig. 3) indicate dominance of detritus transport from the W and SW (Kozłowski et al., 2004). The transport directions confirm the interpretations that the greywacke detritus was derived from the west, i.e., from outside the continent mainland (e.g., Jaworowski, 1971; Malec, 2001).

The top of the Silurian succession in the Kielce Region is formed by the locally preserved Miedziana Góra Conglomerate. The conglomerate is composed of clasts of Ordovician sandstones and Middle Cambrian quartzites (Czarnocki, 1936), referred to the exhumed local, pre-Silurian substratum (Kozłowski, 2008).

The Silurian sedimentary rocks in the Bardo Syncline (Kielce Region, see Fig. 1 for location) are cross-cut by a diabase sill that occurs near the boundary between the Lower Silurian shales and the Upper Silurian greywackes. The rock geochemistry is typical of a continental extensional setting (Krzemiński, 2004). Prefolding magnetization (Nawrocki, 2000) and ${ }^{40} \mathrm{Ar}-{ }^{39} \mathrm{Ar}$ isotope ages at $432 \pm 2 \mathrm{Ma}$ (Nawrocki et al., 2007) and $412 \pm 2$ and $415 \pm 2 \mathrm{Ma}$ (Nawrocki et al., 2013) indicate its formation during basin development.

The Silurian rocks in the Kielce Region were folded prior to the sedimentation of ?Pragian-Emsian sandstones (Kowalczewski and Lisik, 1974) which unconformably cover the Caledonian synclines or, more often, are spread over the Cambrian substratum deformed earlier by the pre-Tremadocian Sandomirian folding. Deformed Silurian sedimentary rocks are preserved only in a few areas - mainly synclines, most probably representing Caledonian graben structures (Fig. 1). The maximum thickness of the most complete Silurian succession in the Małopolska terrane is recorded in the Międzygórz Syncline where the total thickness may exceed 1000 m (Tomczyk, 1954; Tomczyk, 1974: fig. 13; Pożaryski and Tomczyk, 1993: fig. 15). The Lower Paleozoic rocks of the Kielce Region show low maturity of organic matter (CAI 1-2), which indicates its low diagenetic imprint (Narkiewicz, 2002).

In the Łysogóry Region, the Llandoverian to Gorstian graptolitic shales succession, $300 \mathrm{~m}$ thick, is followed by $500 \mathrm{~m}$ thick lithic arenites and shales, referred to the Trzcianka Formation (Kozłowski, 2008). The change from shales to greywackes occurred above the Saetograptus leintwardinensis Zone (Deczkowski and Tomczyk, 1969; Tomczyk, 1970), hence with some delay in relation to the Kielce Region. The Trzcianka Formation, in comparison to the Niewachlów Beds, contains thinner and finer-grained, graded bedding arenite intercalations. The formation comprises many more mudstone interbeddings than its counterpart from the Kielce Region (Kozłowski, 2008). The shale intercalations contain rare graptolites representing Bohemograptus bohemicus which indicates an early Ludfordian age of these rocks (Tomczyk, 1970). Redeposited benthic fauna from the coarsest beds of the Trzcianka Formation is represented only by rare small crinoids (up to $2 \mathrm{~mm}$ across; Kozłowski, 2008). The dominant transport directions in the Łysogóry Region (Fig. 3) were from the WNW (Kozłowski et al., 2004). Above the greywackes of the Trochowiny Formation, there is a monotonous shale-siltstone complex referred to the Trochowiny Formation. It is $550 \mathrm{~m}$ thick and represents the counterpart of the Kielce Beds from the Kielce Region (Kozłowski, 2008). The shallow-marine (e.g., oolitic) sediments above the Trochowiny shales (Kozłowski, 2003), of Middle Ludfordian age (Kozłowski and Munnecke, 2010), indicate that the lower Ludfordian succession filled up the outer part of the shelf and formed a clastic wedge (Kozłowski, 2003) in a foreland setting (Narkiewicz, 2002). The sedimentation in the filled to overfilled (Kozłowski, 2008) stages of the foreland basin evolution continued into the Devonian without any deformation (Czarnocki, 1950). The Silurian rocks in the Łysogóry Region are conformably covered by a thick Devonian succession folded during the Variscan orogeny. The Lower Paleozoic rocks of the Łysogóry Region show a relatively higher maturity of organic material (CAI 3-5) which indicates its medium diagenetic imprint (Narkiewicz, 2002).

\section{MATERIAL AND METHODS}

Samples were collected from macroscopically unweathered, free of carbonate veins, parts of the sandstone beds. Two samples of pebble sandstone (nos. 67 and 70) were collected because finer material was unavailable. Beds considered as representative for the average sandstone lithology for the observed part of succession have been chosen in each outcrop. To avoid the effect of internal components fractionation in- 


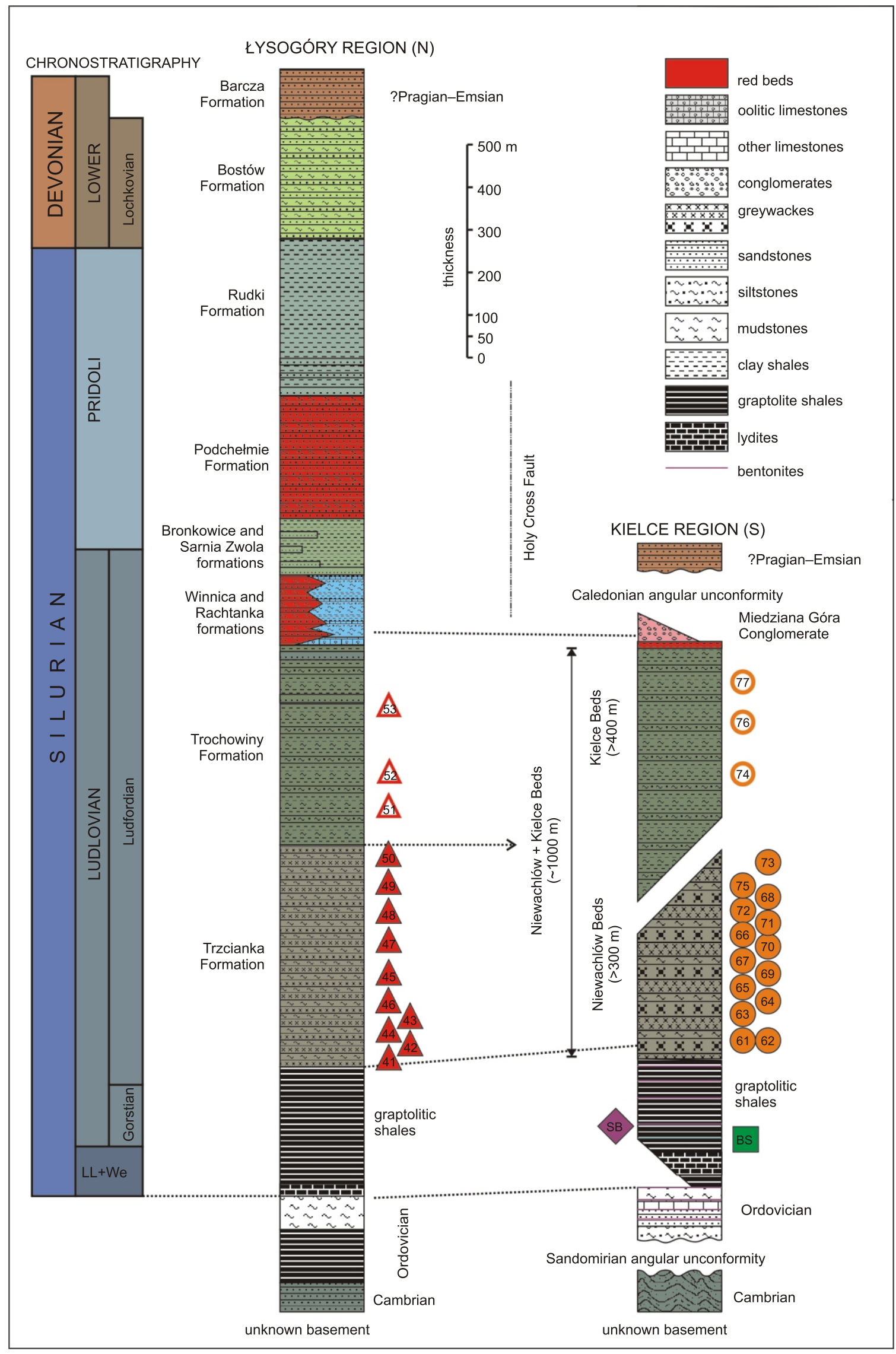

Fig. 2. Lithostratigraphy of the Silurian in the Łysogóry and Kielce regions with the stratigraphic position of the samples (KRG: no. 41-53; KRG: no. 61-77)

BS - Bardo sandstone, SB - Stawy bentonite after Kozłowski (2008); LL+We - Llandoverian and Wenlockian; thicknesses in the Kielce Region partly modified after Tomczyk (1954, 1974: fig. 13), Pożaryski and Tomczyk (1993: fig. 15); other explanations as in Figure 1 


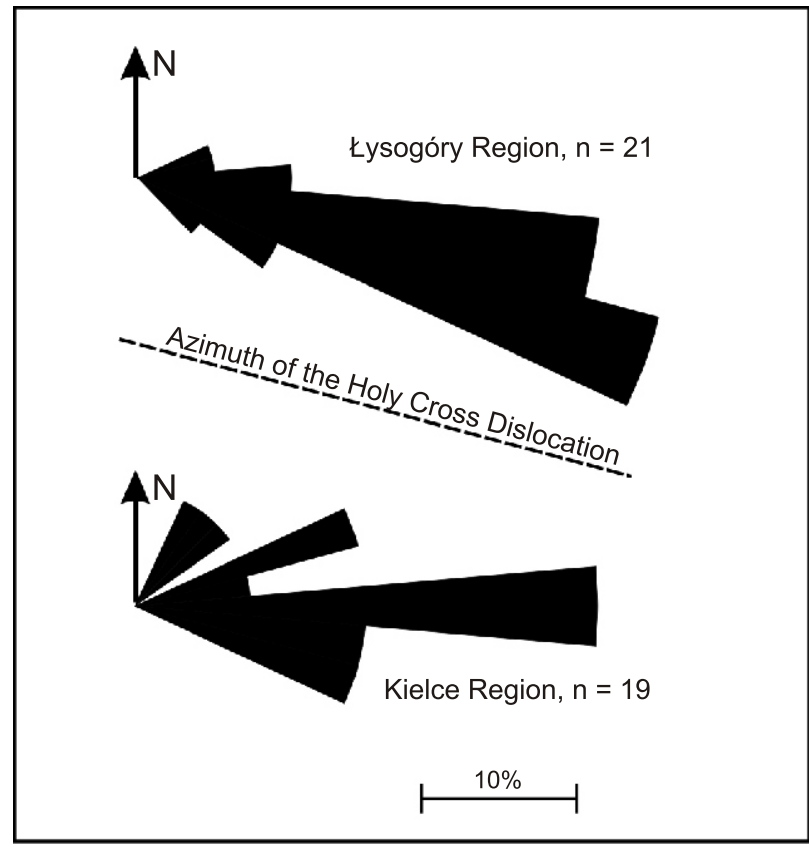

Fig. 3. Diagrams of transport directions (after Kozłowski et al., 2004) of the Ludlovian greywackes from the Łysogóry and Kielce regions (Holy Cross Fault stands for the boundary between the regions)

side the bed, thick beds with internal graded bedding have been omitted. Preferentially, the well-mixed, massive or plane-parallel beds, or exceptionally thin, graded bedded beds (sampled across the whole thickness), were sampled.

Thirty-two samples of greywackes were selected for petrographic and geochemical analyses (Figs. 1B and 2). The sample set of the Kielce Region greywackes (KRG) includes greywackes from the Niewachlów Beds (filled circles in the Figs. 1 and 2) and fine-grained sandstones from the Kielce Beds (open circles in the Figs. 1 and 2). The sample set of the Łysogóry Region ( $\mathrm{RG}$ ) includes greywackes from the Trzcianka Formation (filled triangles in the Figs. 1 and 2) and fine-grained sandstone interbeddings from the Trochowiny Formation (open triangles in the Figs. 1 and 2).

For comparison, the Llandoverian Bardo sandstone (the only Silurian coarse clastic interbedding before the Ludlovian; BS, squares in the Figs. 1 and 2) and the lowermost Wenlockian Stawy bentonite (pre-Ludlovian pyroclastic sediment; SB), were collected and analysed.

The petrographic investigation was based on thin section modal analyses with 300 (coarser beds) to 500 (finer grained) points counting, using the Gazzi-Dickinson method (Dickinson, 1970; Ingersoll et al., 1984). In each thin section, 300 grains were counted separately from the matrix (grains $<0.03 \mathrm{~mm}$ were counted separately as the matrix for the estimation of its content). The matrix content is $22 \%$, indicating slight diagenetic changes of the modal composition, hence allowing to assume that the point-counted modal composition reflects the original composition of the detritus (e.g., Dickinson et al., 1983).

The point components were determined in a $0.0625 \mathrm{~mm}$ diameter area around the crosshairs of the microscope. Detrital grains $<0.0625 \mathrm{~mm}$ were classified simply according to the whole grain composition. Detrital grains $>0.0625 \mathrm{~mm}$ were classified according to their composition exclusively in the target area $(0.0625 \mathrm{~mm}$ diameter-circle), even when they were monomineral components of a larger lithic fragment. This resulted in counting of the coarse-grained (monomineral grains $>0.0625 \mathrm{~mm}$, e.g. plutonic) rocks as individual components (hence the lack of plutonic grains in the results of point counting). The aim of the procedure was to minimize the effect of the grain size on the modes (Gazzi, 1966; Dickinson, 1970).

Cherts, the rest of the polycrystalline quartz grains and monocrystalline quartz with undulatory and straight extinctions, were counted separately. Clasts of sedimentary rocks with visible distinct marks of diagenetic or metamorphic transformations (Lms) and almost unchanged sedimentary grains (Ls) were also counted separately. Plutonic grains, muscovite, biotite, and heavy minerals were counted additionally, independently of the main procedure described above, to estimate their general abundance in the samples.

To calculate the average grain size, the standard deviation (sorting) and skewness were determined, and measurements of the average diameter of 100 grains in each thin section were performed.

The results of the point counting, grain measurements and calculated petrographic parameters are shown in Appendix $1^{*}$.

Whole rock chemical analyses of the samples were performed at ACME Labs, Vancouver, Canada. Abundances of the major oxides and minor trace elements were determined by Inductively Coupled Plasma - Atomic Emission Spectrometry (ICP AES), whereas those of rare earth and refractory elements - using Inductively Coupled Plasma - Mass Spectrometry (ICP MS). The results of the geochemical analyses of the samples are shown in Appendix 2.

The studied rocks have been classified according to the petrographic classification of clastic rocks proposed by Pettijohn et al. (1972) and the geochemical classification of greywackes of Pettijohn et al. (1987). The matrix type has been classified according to Eynatten et al. (2003).

\section{RESULTS}

\section{PETROGRAPHY}

Composition of the Upper Silurian greywackes from the Kielce Region (KRG). The KRG are mostly lithic arenites with minor sublithic to subarkosic arenites and lithic and arkosic wackes (Fig. 4). The rocks are mostly grain-supported, with matrix ranges from 3 to $19 \%$ (with a mean of $11 \%$ ). Texturally they are immature, poorly to moderately sorted and fine- to coarse-grained. Two samples represent fine-grained conglomerates. The matrix is composed of clays and highly altered fine framework grains, therefore it is classified as pseudomatrix.

The grains are sub-angular to rounded. The grain spectrum is dominated by quartz or lithics, with some addition of feldspars (Appendix 1). The average QFL modal composition of the KRG is $Q_{51} F_{16} L_{33}$. The KRG samples have low compositional homogeneity, with a very wide spectrum of the modal composition (Fig. 4, Appendix 2). Quartz grains dominate in majority of the samples, but six of the samples $(64,66,67,68,70$ and 73$)$ contain more lithic fragments than quartz grains. The absolute 


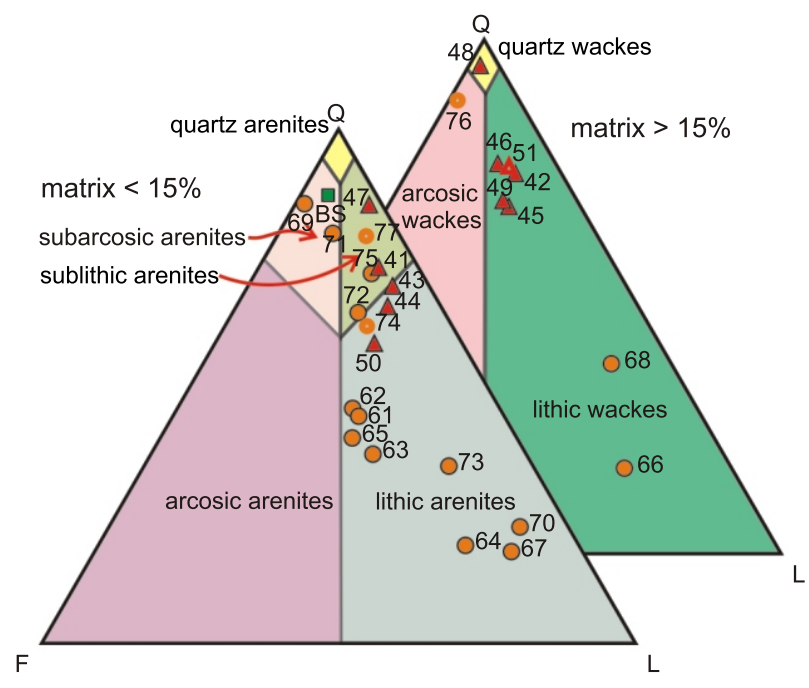

Fig. 4. Petrological classification of the studied sediments based on grain composition (Petttijohn et al., 1972)

$$
\text { F - feldspar, L - lithoclasts, Q - quartz }
$$

abundance of quartz ranges from 18 to $88 \%$ (mean 51\%). Monocrystalline quartz dominates in majority of the samples (mean $\mathrm{Qm}$ in $\mathrm{Q}$ is $65 \%$; see Appendix 1 for abbreviations). Quartz generally shows undulatory extinction (mean Qu in Qm is $64 \%$ ), but in a few samples there is a strong dominance of quartz grains with straight extinction (Qu in Qm 9-25\%). The Qm grains with straight extinction often occur as angular grains with resorbed margins, which may be associated with a rapid cooling process and a volcanic origin (Fig. 6C). Within the KRG, a smaller (than in case of the $Ł R G$ ) part of polycrystalline quartz grains is represented by cherts (mean ch in $\mathrm{Qp}=34 \%$ ).

The KRG rocks contain variously abundant feldspar grains (8-31\%, mean 16\%). The contribution of plagioclase ranges from 21 to $73 \%$ (Appendix 2). Plagioclase grains are commonly sub-angular or sub-rounded with characteristic concentric compositional zoning and polysynthetic twinning (Fig. 6F). K-feldspar appears as orthoclase or rarely microcline (Fig. 6E). All feldspars are moderately altered.

The abundant lithics (mean 35\%) are mainly of volcanic (Fig. 5A-F) or sedimentary origin, with average modal composition $L_{100}=L_{49}+L_{32}+L m_{19}$ (Fig. 6A, B). Volcanic clasts are generally of three types (Fig. 5A-F). The first type is micro-porphyritic andesite with euhedral phenocrysts of moderately altered plagioclase and hornblende (Fig. 5E, F). Most hornblende phenocrysts exhibit rims with abundant cryptocrystalline opaques. The groundmass is dominated by feldspar, quartz, opaque minerals and brown relicts of glass. The second type is microcrystalline rhyolite to dacite with phenocrysts of plagioclase, K-feldspar, quartz (often with resorbed margins), and occasionally biotite (Fig. 5C, D). The last type is trachyte fine-grained aphyric rock with the mineral composition dominated by sanidine. Sanidine is present as microphenocrysts in the groundmass, often with clear, simple twins. The rock exhibits a distinct trachytic texture. Secondary minerals, probably replacing glass or mafic minerals, occur within the interstitial areas (Fig. 5A, B).

Sedimentary rock fragments are represented by fine-grained wackes, siltstones and arenites (Fig. 6A, B). Cherts (included in the Qp grains parameter) are also frequent (Fig. 5G, H), but rarely stand for the dominant type of the sedi- mentary rock fragments (the mean contribution of cherts among all sedimentary rock fragments is $38 \%$ ).

The metamorphic grains contain slightly metamorphosed greywackes to siltstones and less frequent quartzites (Fig. 6B, D). Rare minute clasts of plutonic rocks have granitic compositions and consist of quartz, feldspar and mica.

Detrital mica abundance in the KRG is up to $12 \%$ of grains (mean 5\%). Muscovite and biotite appear in a wide range of ratios. Accessory and heavy minerals constitute $<4 \%$ in all the samples and are mainly represented by zircon, apatite and opaque minerals.

Composition of the Upper Silurian greywackes from the Łysogóry Region (ŁRG). The ŁRG can be classified, in general, as sublithic-lithic arenites, lithic wackes and rarely quartz wackes (Fig. 4). The rocks are grain- to matrix-supported with the matrix content in the range of 8 to $22 \%$ (with the mean of $15 \%)$. The matrix is composed of clays and highly altered fine framework grains, hence it should be classified as pseudomatrix. Texturally, the $Ł R G$ are immature, poorly to moderately sorted and fine- to medium-grained. The main framework grains are sub-angular to rounded. Quartz strongly dominates with some addition of lithics and feldspars. The average QFL modal composition of the $Ł R G$ is $Q_{76} F_{8} L_{16}$. The $Ł R G$ samples have a higher compositional homogeneity than the KRG samples, with a narrower spectrum of modal composition (Fig. 4, Appendix 2). Quartz is the most abundant component within all the samples with the absolute abundance ranging from $59 \%$ to $97 \%$ (mean $76 \%$ ). Monocrystalline quartz in all ŁRG samples is more abundant than polycrystalline quartz (mean $\mathrm{Qm}$ in $\mathrm{Q}=68 \%$ ). Monocrystalline quartz with undulatory extinction is distinctly more abundant than grains with straight extinction in all $Ł R G$ samples (mean Qu in Qm 77\%). Almost half of the polycrystalline quartz grains are cherts (mean ch in $\mathrm{Qp}=43 \%$ ).

Besides quartz, the greywackes contain a wide spectrum of lithics, including volcanic, sedimentary, metamorphic and plutonic (granite type) rock fragments $\left(L_{100}=L_{54}+L_{5}+\right.$ $\mathrm{Lms}_{14}$ ). The most abundant are volcanic clasts of the same types as in the case of the KRG (Fig. 5). They are mostly of intermediate (trachytes, andesites) and, in a minor part, of felsic (rhyolites to dacites) types $\left(L v_{\text {intermediate }}: L V_{\text {felsic }}=3: 1\right)$. Andesites show a micro-porphyritic texture with phenocrysts of euhedral, zoned plagioclase within a fine-grained matrix. Rhyolites and dacites are often metasomatically silicified. They also contain abundant quartz, feldspar and biotite phenocrysts.

Cherts are the most frequent grains of sedimentary origin. Their mean content in all the sedimentary grains is $60 \%$, with $\mathrm{SD}=15.3$. Rarely, fine-grained greywackes and siltstones are also observed. The metamorphic fragments consist mainly of metagreywacke and metasiltstone, while quartzites are less frequent. Rare plutonic rock fragments are represented by granite-type grains composed of quartz, feldspar, muscovite and secondary minerals (chlorite).

The ŁRG samples contain rare feldspars (mean $8 \%$ ). Plagioclase dominates over alkali feldspar in a majority of the samples (mean $\mathrm{P}$ in $\mathrm{F}=53 \%$ ). Plagioclase occurs as polysynthetic twins and sometimes as zoned, sub-angular to sub-rounded crystals. K-feldspar appears as orthoclase, perthite and rarely microcline. Numerous feldspars show alteration to sericite and kaolinite.

Mica abundance is up to $11 \%$ of grains (mean 5.5\%). Muscovite, in general, dominates over biotite. Accessory and heavy minerals constitute $<3 \%$ of the samples and are mainly represented by zircon, apatite and opaque minerals. 

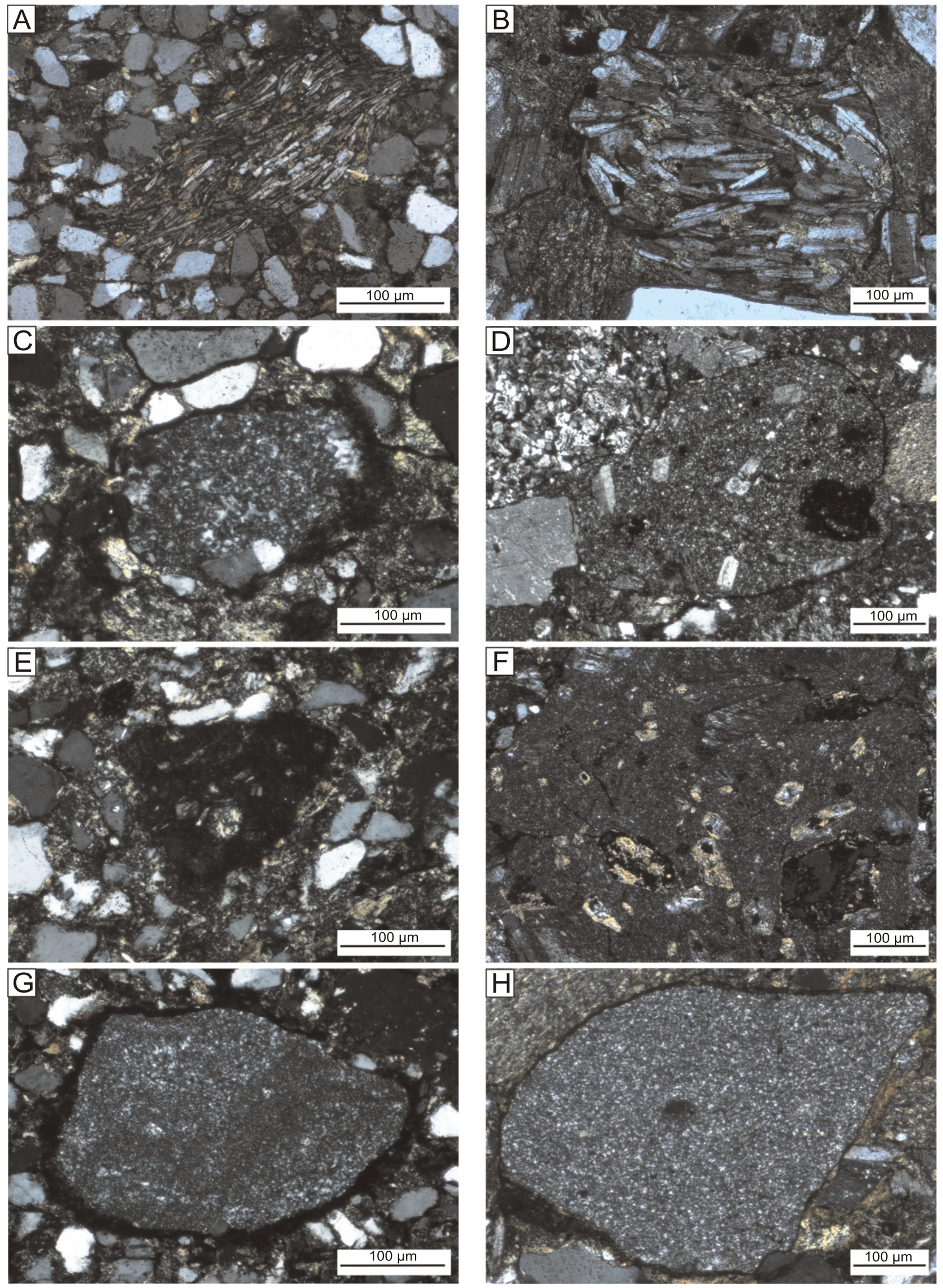

Fig. 5. Photomicrographs of greywackes showing a similarity of the clast types in the ŁRG (A, C, E, G) and KRG (B, D, F, H)

A, B - trachyte clasts; C, D - rhyolite/dacite clasts; E, F - andesite clasts; G, H - chert clasts; all photographs taken under crossed polars 

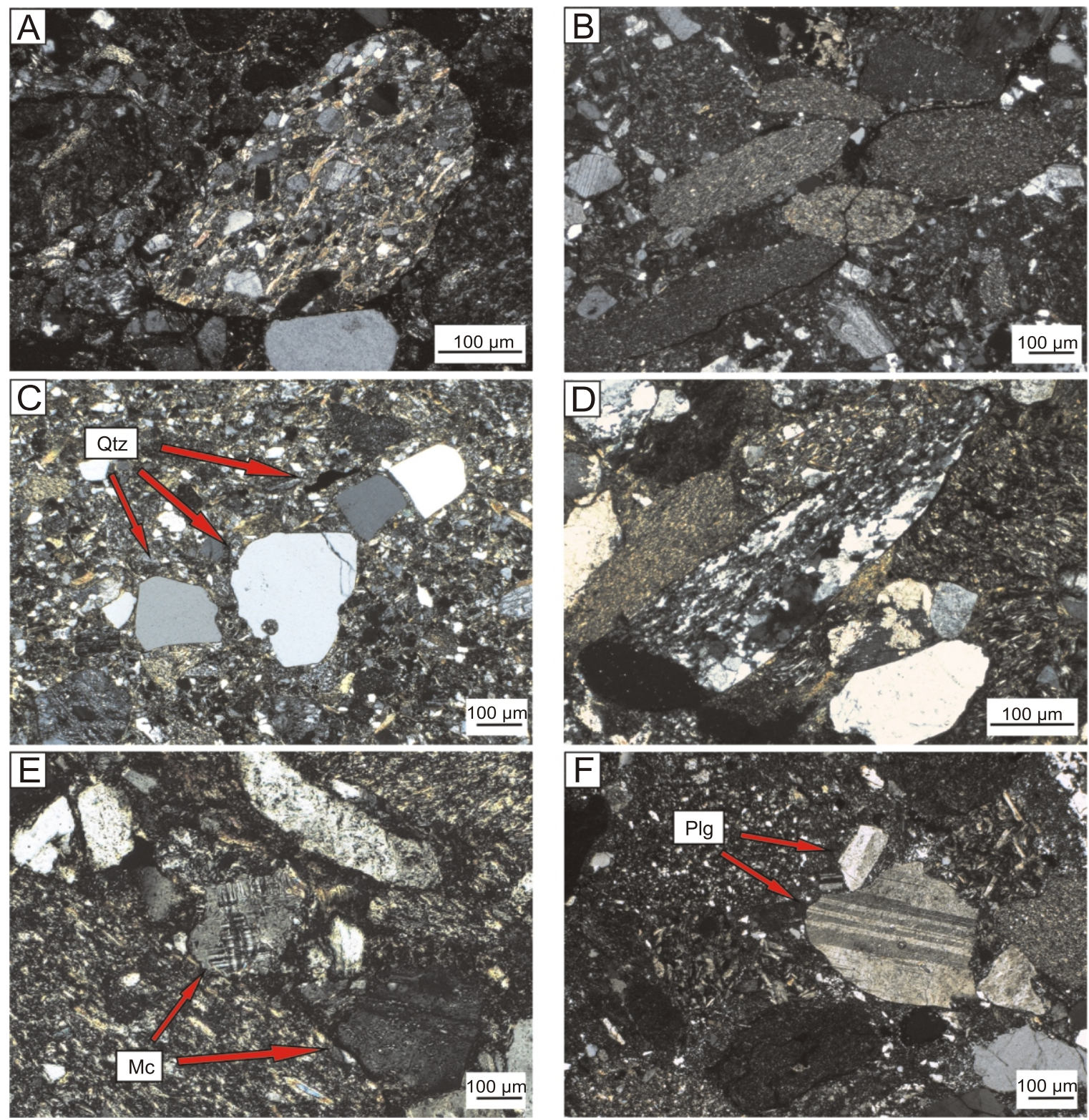

Fig. 6. Photomicrographs of greywackes showing clasts other than the volcanic type

Examples come from the KRG: A, B - sedimentary clasts; C - corroded quartz grains of volcanic origin;

D - metamorphic clast (quartzite); E - microcline grain; F - plagioclase grain; Mc - microcline; Plg - plagioclase; Qtz - quartz; all photographs taken under crossed polars

Composition of the Bardo sandstone (BS Llandoverian). The BS is classified as subarkosic arenite: moderately coarse-grained, grain-supported (grains content $94 \%$ ), texturally mature and moderately sorted. The main framework grains comprise rounded quartz, with a small addition of feldspar and lithics. The QFL modal composition of the $B S$ is $Q_{88} \mathrm{~F}_{8} \mathrm{~L}_{4}$. Within the quartz grains population, monocrystalline ( $\mathrm{Qm}$ in $\mathrm{Q}=72 \%$ ) undulatory (Qu in $\mathrm{Qm}=85 \%$ ) quartz is the most abundant type. Cherts constitute only a subordinate part of the polycrystalline quartz grains (ch in $\mathrm{Qp}$ is $12 \%)$. Feldspar grains are mainly $\mathrm{K}$-feldspar ( $\mathrm{P}$ in $\mathrm{F}=23 \%$ ) with abundant microcline. All the feldspars are strongly altered. The lithoclasts are mostly represented by fragments of sedimentary rocks (quartz arenites and siltstones). The detrital muscovite abundance of the BS amounts to $\sim 2 \%$ of grains. Biotite is less frequent $(\sim 1 \%)$. Accessory minerals are represented by glauconite $(\sim 4 \%)$ and zircon.

\section{GEOCHEMICAL COMPOSITION OF THE GREYWACKES}

Major elements. The concentrations of the major elements analysed in the samples are provided in Appendix 2. According to the geochemical classification, both sample suites are dominated by litharenites with minor subarkoses and greywackes (KRG; Fig. 7), which is consistent with the petrographic observations. The studied rocks have a high Index of Compositional Variability (ICV; Cox et al., 1995) indicating that they are geochemically immature (1.27 for $Ł R G$ and 1.1 for KRG).

The greywackes from the Kielce Region (KRG) generally show wider and lower average $\mathrm{SiO}_{2}$ concentrations (65-88\%, 


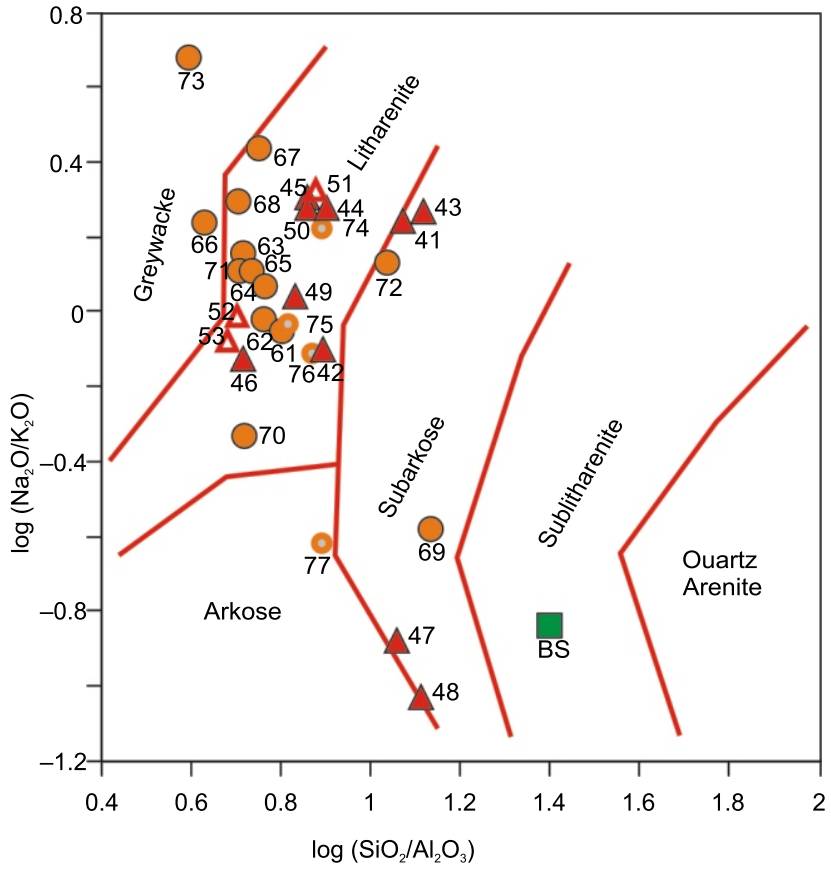

Fig. 7. Geochemical classification of the Silurian greywackes from the Holy Cross Mountains (classification diagram after Pettijohn et al., 1987)

Explanations as in Figure 1

mean $74.17 \%$ ) than the greywackes from the Łysogóry Region (ŁRG; 68-85\%, mean 76.97\%). In comparison to the Post-Archean Australian Shale (PAAS; Taylor and McLennan, 1985), the samples yield low $\mathrm{Al}_{2} \mathrm{O}_{3}$ (12.18 and $10.03 \%$ on average, respectively). The $\mathrm{Al}_{2} \mathrm{O}_{3} / \mathrm{SiO}_{2}$ ratios of the $\mathrm{KRG}$ are generally higher (with a mean of 0.17 ) than the $\mathrm{Al}_{2} \mathrm{O}_{3} / \mathrm{SiO}_{2}$ ratios of the $\measuredangle R G$ (with a mean of 0.13 ). The $\mathrm{Al}_{2} \mathrm{O}_{3}$ content shows a distinct negative correlation with the $\mathrm{SiO}_{2}$ abundance over the entire sample set (Fig. 8). It may suggest hydrodynamic sorting between sand and clay (e.g., Roser, 2000). However, the alumina-rich samples of the KRG represent relatively the coarsest arenites with a low clay content, hence the elevated $\mathrm{Al}_{2} \mathrm{O}_{3} / \mathrm{SiO}_{2}$ ratios of the KRG, probably reflecting higher amount of feldspars plus lithic fragments. It may be confirmed by the positive correlations $\left(\left\lfloor R G r^{2}=0.61 ; \mathrm{KRG} r^{2}=0.81\right)\right.$ of the $\mathrm{Al}_{2} \mathrm{O}_{3}$ content with the total (molar) amount of alkalis (Fig. 8). The total concentration of $\mathrm{K}_{2} \mathrm{O}, \mathrm{Na}_{2} \mathrm{O}$ and $\mathrm{CaO}$ in the $\mathrm{KRG}$ suite is generally two times higher (average around $4 \%$ ) than in the $Ł R G$ sample group (average around $2 \%$ ). The studied sedimentary rocks show a wide spectrum of $\mathrm{K}_{2} \mathrm{O} / \mathrm{Na}_{2} \mathrm{O}$ ratios in case of both the suites, however with a distinct dominance of ratios below 1 . The $\mathrm{CaO} *$ ( $\mathrm{CaO}$ after apatite correction) abundances are low (below $1 \%)$ and in the case of the KRG they are positively correlated with the $\mathrm{Na}_{2} \mathrm{O}$ content $\left(r^{2}=0.47\right.$; in the case of $\left.七 R G r^{2}=0.06\right)$. It suggests that the alkali contents are controlled by plagioclase at least in the KRG suite.

The Harker variation diagram of the $\mathrm{TiO}_{2}$ against $\mathrm{Al}_{2} \mathrm{O}_{3}$ abundances (Fig. 8) does not show clear differences between the spectrum of the $\mathrm{TiO}_{2} / \mathrm{Al}_{2} \mathrm{O}_{3}$ ratios in the two sample suites. The moderate positive correlation between both abundances of oxides suggests that $\mathrm{Ti}$ is in large part contained in the phyllosilicates (Condie et al., 1992). The $Ł R G$ show in general a stronger depletion in $\mathrm{P}_{2} \mathrm{O}_{5}$ and $\mathrm{MnO}$ in comparison to the $\mathrm{KRG}$ suite (Appendix 2).
Both sample suites reveal relatively high $\mathrm{Fe}_{2} \mathrm{O}_{3}$ abundances (mean KRG: 6.32\%; mean ŁRG: 8.89\%) and moderate $\mathrm{MgO}$ abundances (mean KRG: $1.69 \%$; mean ŁRG: $1.35 \%$ ). The $\mathrm{MgO}$ abundances show consistent positive correlation with the $\mathrm{Al}_{2} \mathrm{O}_{3}$ content in the whole sample set (Fig. 8). The $\measuredangle R G$ and part of the relatively quartz-rich KRG samples show relative enrichment in $\mathrm{Fe}$. $\mathrm{Fe}_{2} \mathrm{O}_{3}$ plotted against the $\mathrm{K}_{2} \mathrm{O}$ abundances (Fig. 8) indicates a contrast between this assemblage and the rest of the samples. The $\measuredangle R G$ and part of the low- $\mathrm{Al}_{2} \mathrm{O}_{3} / \mathrm{SiO}_{2}$ KRG samples show $\mathrm{Fe}_{2} \mathrm{O}_{3} / \mathrm{K}_{2} \mathrm{O}$ ratios above 5, characteristic of Fe-sandstones, whereas the remaining KRG samples show $\mathrm{Fe}_{2} \mathrm{O}_{3} / \mathrm{K}_{2} \mathrm{O}$ ratios between 5 and 1 - characteristic of litharenites (Herron, 1988). The observed contrast may indicate a different diagenetic history of both groups, with influence of siderite formation in the ŁRG suite (occasionally found in the succession as concretions) and in the top part of the KRG (Kielce Beds). The major part of the quartz-poor KRG samples shows negative correlation between K and Fe oxides (Fig. 8), probably reflecting mixing between the lithic and feldspar components and various admixtures of biotite.

In comparison with the Ludlovian greywackes, the Llandoverian Bardo sandstone (BS) shows higher $\mathrm{SiO}_{2}$ concentrations (89.35), lower $\mathrm{TiO}_{2}$ abundances $(0.38 \%)$, lower total $\mathrm{Fe}_{2} \mathrm{O}_{3}+\mathrm{MgO}$ concentrations (2.8\%), much lower $\mathrm{Al}_{2} \mathrm{O}_{3} / \mathrm{SiO}_{2}$ ratio (0.04) and much higher $\mathrm{K}_{2} \mathrm{O} / \mathrm{Na}_{2} \mathrm{O}$ ratio (6.79). The Bardo sandstone in relation to the Ludlovian greywackes shows a stronger depletion in $\mathrm{MnO}$ and is clearly enriched in $\mathrm{P}_{2} \mathrm{O}_{5}$.

Trace elements. Trace element concentrations in the samples are given in Appendix 2. In the multi-element diagram (after Floyd et al., 1991) normalized to the Upper Continental Crust (UCC - values after Taylor and McLennan, 1985), the $K R G$ and $Ł R G$ samples show a significant depletion in mobile large ion lithophile elements (LILE), i.e., $\mathrm{K}, \mathrm{Rb}, \mathrm{Sr}$, and $\mathrm{Ba}$, higher than the UCC concentrations of the ferromagnesian elements $(\mathrm{V}, \mathrm{Cr}, \mathrm{Ni})$, and a moderate depletion in high field strength elements (HFSE) represented by Ta and Nb (Fig. 9). The KRG and $Ł R G$ samples show typical of the UCC abundances of Sc, Ti and heavy rare earth elements (HREE), however, with parallel relative depletion in light rare earth elements (LREE) and Th. The ŁRG and quartz-rich KRG samples have a stronger enrichment in heavy mineral elements $(\mathrm{Hf}-\mathrm{Y})$ in comparison to the quartz-poor KRG samples. The $Ł R G$ show an overall depletion in immobile trace elements in relation to the KRG, with strong positive correlation between Th and Sc (ŁRG $\left.r^{2}=0.59\right)$, not observed in the KRG suite $\left(r^{2}=0.07\right)$.

Rubidium abundances in the $Ł R G$ and quartz-rich KRG samples show a significant correlation with the $\mathrm{K}$ abundances (K/Rb ratio close to the crustal average of 230). The quartz-poor KRG samples show a relative $\mathrm{K}$ over $\mathrm{Rb}$, enrichment with the $\mathrm{K} / \mathrm{Rb}$ ratios up to 425 (Fig. 8). This value is atypical for continental crust sources. The lower values of the K/Rb ratio in the $\measuredangle R G$ suite may be controlled by relative $\mathrm{Rb}$ enrichment in more differentiated source rocks (Shaw, 1968) and/or their longer weathering history manifested in relative $\mathrm{K}$ depletion (Heier and Billings, 1970).

Strontium abundances show a significant correlation with $\mathrm{CN}\left(\mathrm{CaO}^{*}+\mathrm{Na}_{2} \mathrm{O}\right.$ mole abundances with *apatite correction for $\mathrm{CaO}$ ) in the quartz-poor KRG samples (Fig. 8). It suggests plagioclase as the dominant $\mathrm{Ca}-, \mathrm{Na}$ - and $\mathrm{Sr}$-bearing mineral in the samples. The remaining sample set contains relatively low but constant $\mathrm{Sr}$ abundances (Fig. 8). Hence, the Sr abundances in quartz-rich samples are probably controlled by a variable proportion of plagioclase and clay minerals (the latter with adsorbed $\mathrm{Sr}$ ). Barium abundances show a positive correlation 

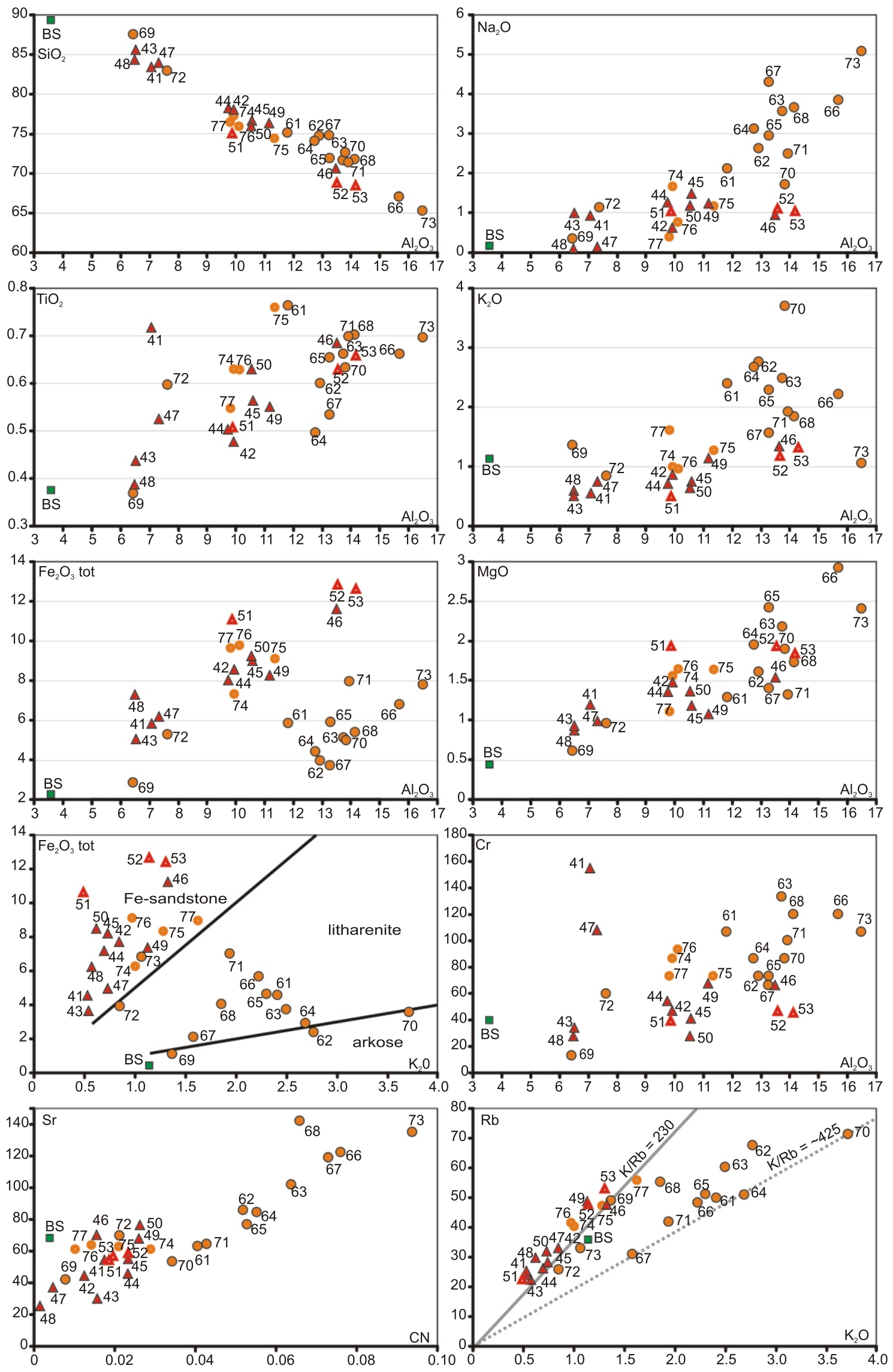

Fig. 8. Selected element - major oxide variation diagrams for the Silurian greywackes from the Holy Cross Mountains

Explanations as in Figure 1 

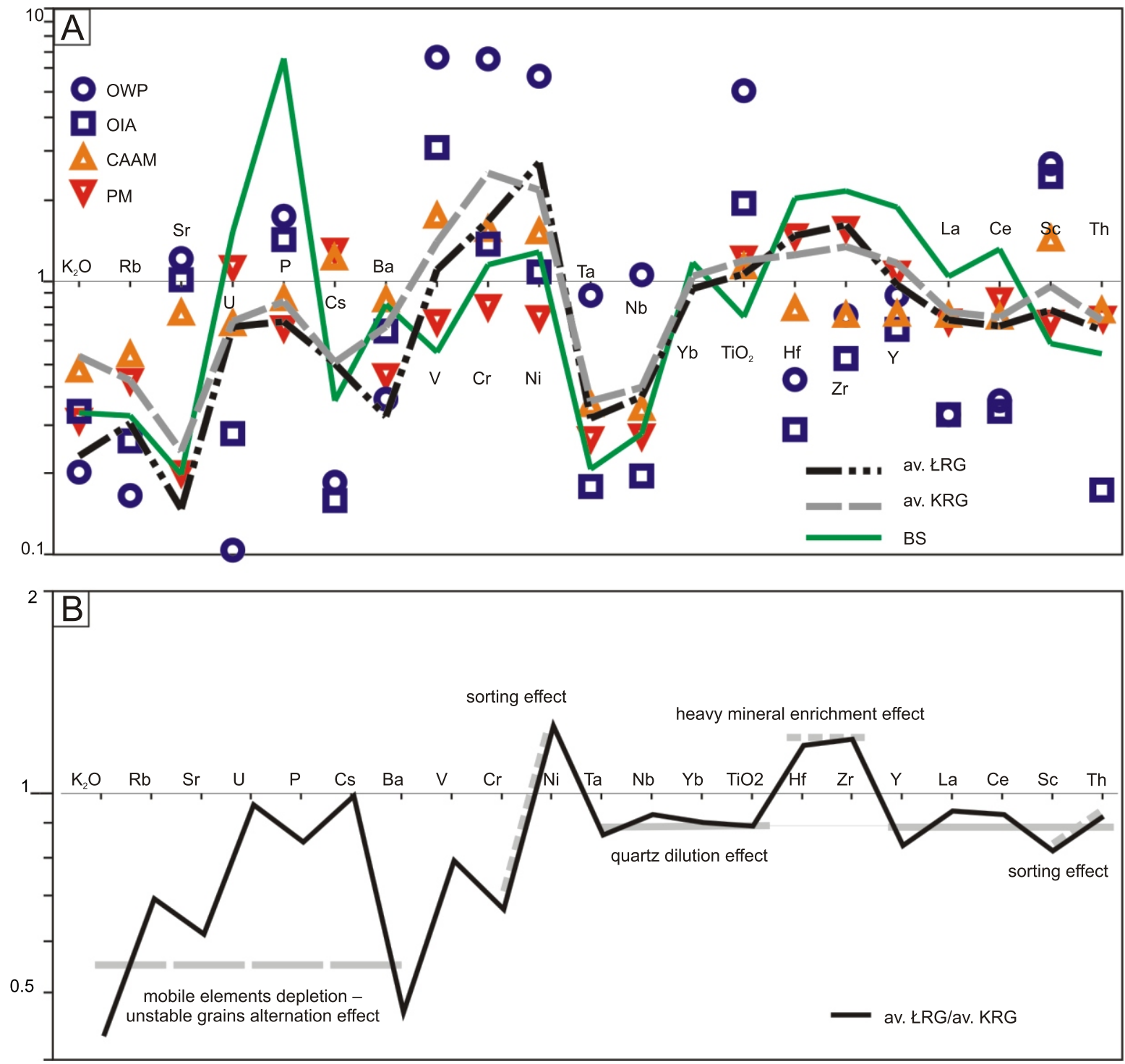

Fig. 9A - multi-element patterns for the average KRG, ŁRG and the Bardo sandstone (BS) normalized to the Upper Continental Crust (values after Taylor and McLennan, 1985; method after Floyd et al., 1991); B - the ŁRG/KRG comparison diagram showing higher alteration and more passive margin signatures of the $Ł R G$

The values typical of the average composition of the Late Proterozoic and Phanerozoic greywackes associated with the passive margin (PM), continental island arc + active continental margin (CAAM), oceanic island arc (OIA), and oceanic within plate setting (OWP) - after Floyd et al. (1991)

with $\mathrm{K}$ (not illustrated) and are three times lower as compared to the UCC in the ŁRG and quartz-rich KRG samples. The quartz-poor KRG samples have Ba abundances only slightly depleted in relation to the UCC.

The KRG and $Ł R G$ suites are significantly enriched in ferromagnesian trace elements $(\mathrm{Cr}, \mathrm{V}, \mathrm{Ni})$ in relation to the UCC (Fig. 9). The ŁRG is enriched in $\mathrm{Ni}$ and depleted in $\mathrm{Cr}$ in comparison to KRG, which may indicate fractionation between these elements during more intense weathering and sorting of the ŁRG (Floyd et al., 1989; Feng and Kerrich, 1990). Beside the quartz dilution effect estimated from abundances of other elements, the ŁRG show some additional depletion in Sc and $Y$ in relation to the KRG.

The Bardo sandstone, in relation to the Ludlovian greywackes, shows a depletion in LILE, significant depletion in ferromagnesian trace elements, depletion in HFSE and significant enrichment in heavy mineral elements (Fig. 9). The abun- dance of HREE (Yb) and LREE (La) typical of the UCC, along with the distinct enrichment in $\mathrm{Ce}$ and $\mathrm{P}$, may indicate an important admixture of monazite in the heavy mineral spectrum.

Rare Earth Elements (REE). The total REE abundances are similar for both $€ R G$ and KRG samples (average 109.3 and 122.4, respectively), and are in both cases lower than in PAAS (185 ppm, Taylor and McLennan, 1985) and UCC (146 ppm, McLennan, 1989). In the relatively low-matured KRG suite, the $\Sigma$ REE does not exceed 150 ppm, whereas in the quartz-rich Bardo sandstone the $\Sigma$ REE is typical of PAAS (186 ppm). It suggests a relatively low abundance of $\Sigma$ REE in the source rocks of the KRG and $\measuredangle R G$, additionally diluted by quartz in the case of the ŁRG suite (e.g., Taylor and McLennan, 1985; Bock et al., 2000).

In the KRG suite, there is a significant positive correlation between the abundances of $\Sigma$ REE and $\mathrm{Hf}-\mathrm{Zr}\left(r^{2}=0.67\right.$, $\left.r^{2}=0.58\right)$ and $\operatorname{Th}\left(r^{2}=0.63\right)$, and a moderate positive correla- 
tion between the $\Sigma$ REE and $\mathrm{Nb}, \mathrm{Ti}\left(r^{2}=0.3, r^{2}=0.26\right)$, and $\mathrm{P}_{2} \mathrm{O}_{5}$ $\left(r^{2}=0.17\right)$ abundances. In the case of the $Ł R G$ samples, the correlation between the abundances of $\Sigma \mathrm{REE}$ and $\mathrm{Hf}-\mathrm{Zr}$ does not occur $\left(r^{2}=0.0\right)$. However, high to moderate positive correlations of $\Sigma$ REE with Th $\left(r^{2}=0.51\right), \mathrm{Nb}, \mathrm{Ti}\left(r^{2}=0.51, r^{2}=0.41\right)$ and $\mathrm{P}_{2} \mathrm{O}_{5}\left(r^{2}=0.25\right)$ are present. In the $\measuredangle R G$ suite, additional moderate correlations between $\mathrm{REE}$ and the $\mathrm{Al}_{2} \mathrm{O}_{3} / \mathrm{SiO}_{2}$ ratio $\left(r^{2}=0.21\right)$, and between $\Sigma$ REE and the $\mathrm{K}$ and $\mathrm{Sr}$ abundances ( 0.2 and 0.48 , respectively) can be observed.

The difference between the $Ł R G$ and the KRG in the $R E E-Z r$ correlation may be explained by the presence of different carriers of $Z r$ in these sample suites. The moderate negative correlation between $\mathrm{Zr}$ and $\mathrm{Al}_{2} \mathrm{O}_{3}$ in the $\measuredangle R G\left(r^{2}=0.35\right)$ suggests $\mathrm{Zr}$ abundances controlled by free zircon grains in this suite (see e.g., Roser, 2000). In the KRG, the negative correlation is very low $\left(r^{2}=0.14\right)$, hence the $\mathrm{Zr}$ abundances are controlled rather by specific lithic fragments, i.e., clast spectrum composition unrelated to sorting. The low importance of free zircon grains as carriers of REE in the KRG, despite of the strong correlation of $\mathrm{Zr}$-REE abundances, is suggested by the low negative correlation between the $\mathrm{Zr}$ abundance and the $L a_{N} / Y b_{N}$ ratio $\left(r^{2}=0.1\right)$. Because zircon shows an almost linear HREE over LREE fractionation (Belousova et al., 2002), a negative correlation between the $\mathrm{Zr}$ abundance and the $\mathrm{L} \mathrm{a}_{N} / \mathrm{Yb}_{\mathrm{N}}$ ratio should be expected in the case of the zircon suite of REE. Moreover, the total REE abundances of the KRG also show a very low correlation with the $\mathrm{Gd}_{N} / \mathrm{Yb}_{N}$ ratio, which should be lowered in the case of zircon addition (McLennan, 1989).

The second important relationships, particularly in the case of the $Ł R G$, are significant correlations between the REE content and $\mathrm{Th}, \mathrm{Ti}$, and $\mathrm{Nb}$ abundances, with additional distinct correlations between these elements ( $七 R G$ : $\mathrm{Th}-\mathrm{Ti}^{2}=0.7$; $\mathrm{Th}-\mathrm{Nb} r^{2}$ = 0.68; KRG: Th-Ti $r^{2}=0.19$; Th-Nb $r^{2}=0.59$ ). The consistent variations in the REE-Th-Ti-Nb abundances may suggest REE-, Ti-, and Nb-bearing minerals, e.g., euxenite, titanite, allanite and monazite, as the main carriers of REE in the $\measuredangle R G$, and also their admixture in the KRG (Condie et al., 1992). The $Ł R G$ and $K R G$ show a $G d_{N} / Y_{b_{N}}$ ratio above 2, which may confirm a monazite addition in some of the samples (McLennan et al., 1993).

The greywackes of both regions of the $\mathrm{HCM}$ are characterised by a moderate LREE over HREE enrichment (average $L a_{N} / Y b_{N}$ for the $七 R G=7.14$; average $L a_{N} / Y b_{N}$ for the $\mathrm{KRG}=6.98)$, a low to moderately negative Eu anomaly $\left(\mathrm{Eu} / \mathrm{Eu}^{*}\right.$ for the $Ł R G=0.65-0.78,0.72$ on the average; for the KRG it is $0.62-0.91,0.72$ on the average), and a moderately flat HREE pattern (av. $\mathrm{Gd}_{N} / \mathrm{Yb}_{\mathrm{N}}$ for $Ł R G=1.62$; av. $\mathrm{Gd}_{N} / \mathrm{Yb}_{\mathrm{N}}$ for $\mathrm{KRG}=1.77$; Fig. 10A).

Normalized REE patterns for the average KRG and ŁRG are almost identical (Fig. 10A, B). However, individual samples in both the suites show high variations in their REE patterns (Fig. 10C-F), indicating a complex source consisting of various components. The observed variants of REE patterns in both sample suites are compatible, reflecting the presence of similar components.

\section{INTERPRETATION}

\section{DETRITUS ALTERATION}

During weathering, sorting and recycling of detritus, a lot of conversions take place, which may be monitored by the evolution of geochemical and petrological features. The sum of the geochemical changes may be measured by the chemical index of alteration (CIA; Nesbit and Young, 1982) and monitored on the A-CN-K ternary diagram. This diagram (Fig. 11) shows molecular proportions of $\mathrm{Al}_{2} \mathrm{O}_{3} /\left(\mathrm{CaO}^{*}+\mathrm{Na}_{2} \mathrm{O}\right) / \mathrm{K}_{2} \mathrm{O}$, where $\mathrm{CaO}^{*}$ represents silicates only. The studied samples are, in general, carbonate-free. Hence, because of the lack of $\mathrm{CO}_{2}$ concentration data, we could only recalculate the $\mathrm{CaO}^{*}$ abundance with apatite correction. After apatite correction, all the samples show a higher or equal mole fraction of $\mathrm{Na}_{2} \mathrm{O}$ in comparison to $\mathrm{CaO}^{*}$ (Fig. 11B), and in these cases the $\mathrm{CaO}^{*}$ value is accepted (Bock et al., 1998).

The inconsistent distributions of the two sample suites shown on the A-CN-K diagram (Fig. 11) indicate differences in the source material and/or the course of the alteration of detritus in both HCM regions. The ŁRG show higher CIA values (74-89.6; mean 79) than the KRG (59-80; mean 67). This difference is attributed to the higher abundance of total alkalis in the KRG (about 4-5\%) than in the ŁRG (about 1.5-2\%), and a similar abundance of $\mathrm{Al}_{2} \mathrm{O}_{3}(12.18 \%$ and $10.3 \%$, respectively). Weathering of the plagioclase component monitored by the Plagioclase Index of Alteration (PIA) is also different. The distributions of the $Ł R G$ on the A-C-N diagram (Fig. 11B) also indicate its higher alteration in comparison to the KRG. Stronger chemical alteration of the $Ł R G$ is confirmed by their average $\mathrm{Ti} / \mathrm{Na}$ ratio (1.47), which is distinctly higher than for the KRG (0.42).

Differences in the alteration of the greywackes from both the study areas are also clearly visible in other proxies of petrographic and geochemical maturity. The $Ł R G$ detritus is strongly depleted in unstable grains $(F+L v)$ in relation to the KRG (abundances are up to $18 \%$ and $33 \%$, respectively). This is consistent with the depletion of mobile elements, i.e., $\mathrm{K}, \mathrm{Rb}$, $\mathrm{Sr}$, and $\mathrm{Ba}$ in the $Ł R G$ in relation to the KRG (Fig. 9). The ŁRG detritus contains also more abundant resistant grains represented by quartz (average $Q$ abundances of the $Ł R G$ and KRG are up to $76 \%$ and $51 \%$, respectively) and zircon (average $\mathrm{Zr}$ abundances are $305 \mathrm{ppm}$ and $251 \mathrm{ppm}$, respectively). From the geochemical point of view, the effect of dilution in quartz (e.g., Bock et al., 2000) is observed in $Ł R G$, manifested as the depletion of all immobile trace elements (Fig. 9) and REE (Fig. 10), with preserved respective ratios between them.

\section{GENERAL COMPOSITION OF SOURCE ROCKS AND DETRITUS RECYCLING AND MIXING}

In the case of simple weathering of detritus derived from one magmatic consistent source, a linear trend subparallel to the $\mathrm{A}-\mathrm{CN}$ line of the A-CN-K diagram often occurs (ideal weathering trend - IWT). In such a case, a general geochemical composition of a parent rock may be interpreted (Fedo et al., 1995) from the dissection of sample trend data with the feldspar line. In the case of mixing of detritus coming from different sources (McLennan et al., 1993), or post-depositional K-metasomatosis (Fedo et al., 1995), the sample trend lines are not parallel to the IWT.

On the A-CN-K diagram (Fig. 11A), the trends of KRG samples do not cut the plagioclase-K-feldspar line and show a wide spectrum of $\mathrm{K} / \mathrm{CN}$ ratios at a low level of CIA values, with only a minor increase of $\mathrm{CIA}$ values parallel to the increase of the $\mathrm{K} / \mathrm{CN}$ ratio. It can be attributed to the broad spectrum of the plagioclase/total feldspar ratio (P/F), which is also noted in the petrographic analysis and positively correlated with the $\mathrm{CN} / \mathrm{CNK}$ ratios $\left(r^{2}=0.55\right)$ within the slightly alternated KRG samples. In this group of samples (CIA below 70) the K/CN ratio is strongly correlated $\left(r^{2}=0.62\right)$ with the $\mathrm{Sr}$ abundance (normalized to $\mathrm{Al}_{2} \mathrm{O}_{3}$ ). It indicates that the $\mathrm{K} / \mathrm{CN}$ ratio depends on the various abundances of plagioclase, and the K-metasomatosis 

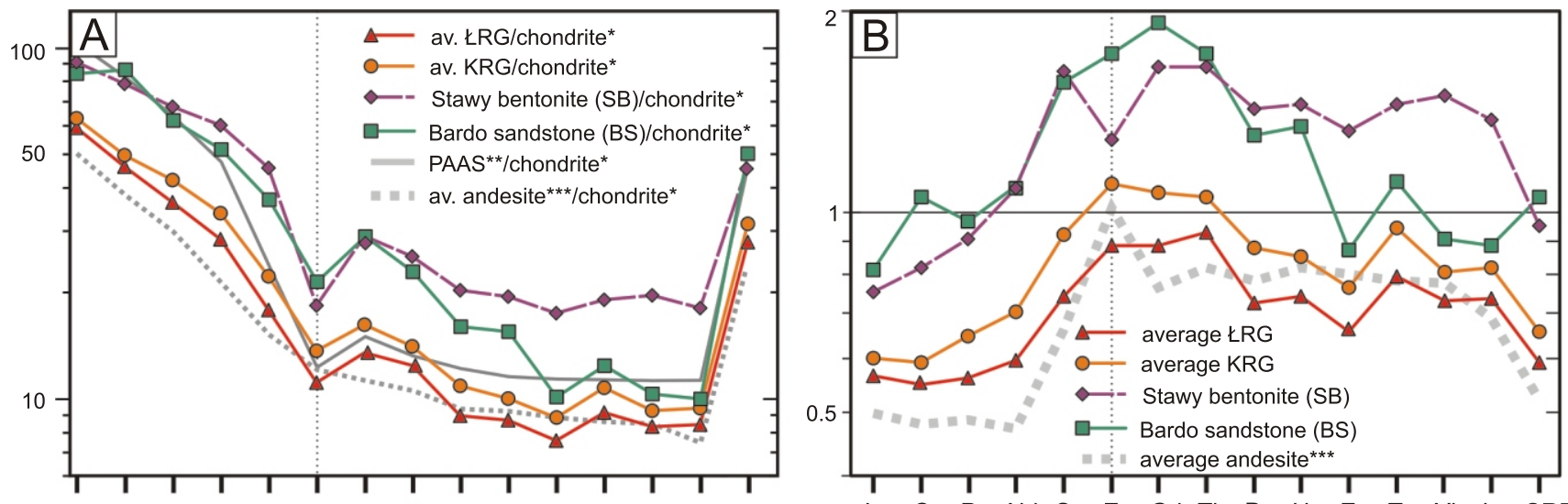

La Ce Pr Nd Sm Eu Gd Tb Dy Ho Er Tm Yb Lu SREE

La $\mathrm{Ce} \mathrm{Pr} \mathrm{Nd} \mathrm{Sm} \mathrm{Eu} \mathrm{Gd} \mathrm{Tb} \mathrm{Dy} \mathrm{Ho} \mathrm{Er} \mathrm{Tm} \mathrm{Yb} \mathrm{Lu} \mathrm{SREE}$
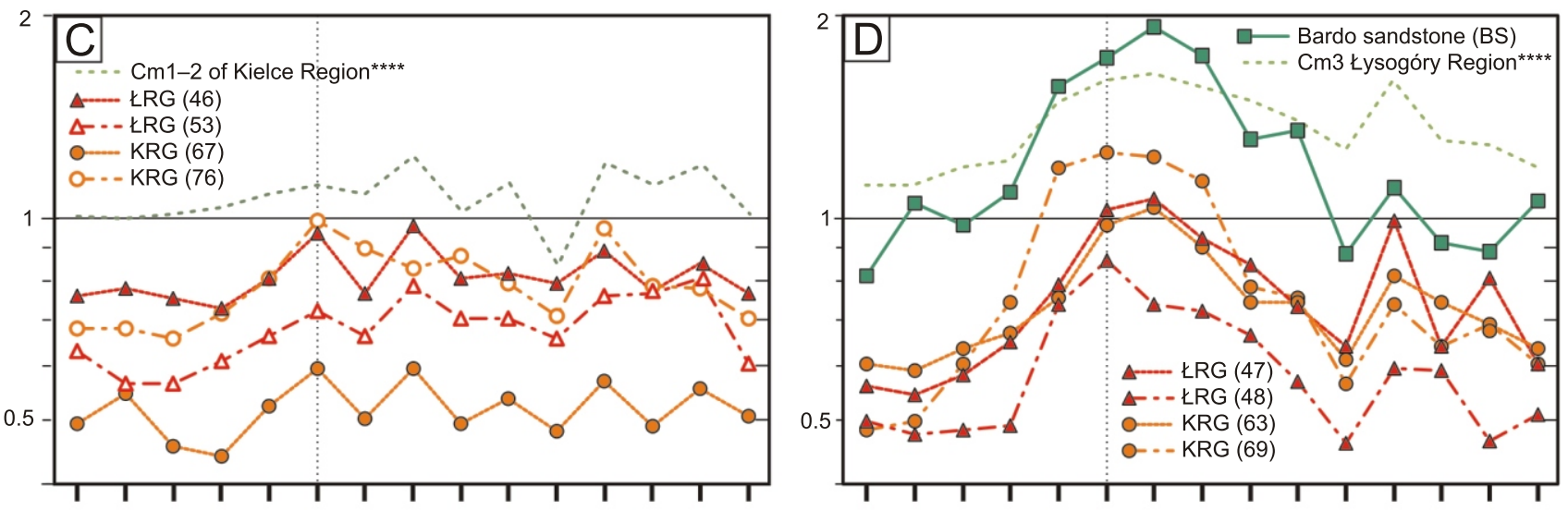

La Ce Pr Nd Sm Eu Gd Tb Dy Ho Er Tm Yb Lu SREE

La $\mathrm{Ce} \operatorname{Pr} \mathrm{Nd} \mathrm{Sm} \mathrm{Eu}$ Gd Tb Dy Ho Er Tm Yb Lu SREE
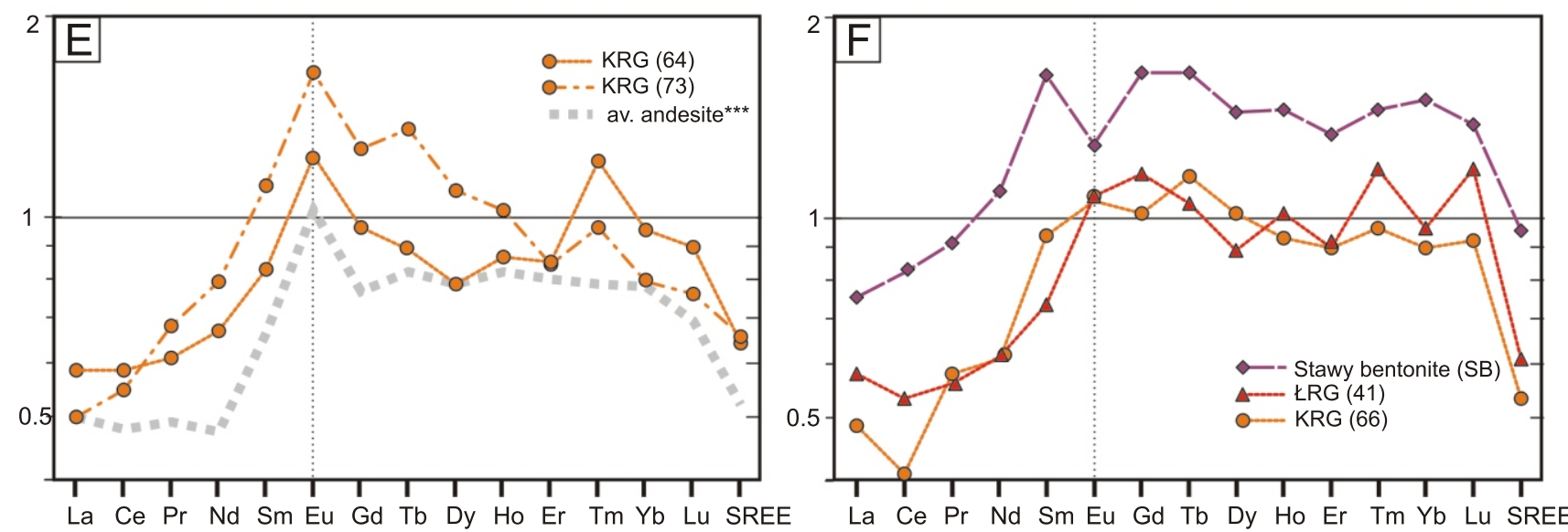

Fig. 10A - average REE patterns ( ${ }^{*}$ - chondrite REE abundances after Taylor and McLennan 1985) of the studied rocks (KRG, ŁRG, Bardo sandstone, Stawy bentonite; after Kozłowski et al., 2004) in comparison to the PAAS (** - REE abundances after Taylor and McLennan 1985) and average andesite (*** - after McLennan, 1989); B-F - REE patterns of individual samples related to the various components of the common source (*** - Cambrian substratum REE abundances after Nawrocki et al., 2007); note the same spectrum and similar average REE patterns for both KRG and ŁRG

of the rocks is not the main process modifying the $\mathrm{K} / \mathrm{CN}$ ratio. The parallel presence of a wide spectrum of volcanic clasts (from andesite and trachyte to dacite), and lack of traces of intense feldspar K-metasomatosis in petrographic observations, suggest a high influence of mixing of the detritus coming from a compositionally differentiated source or from various sources. This scenario is confirmed by the moderately positive correlations between the K/CNK ratio and proxies of the rate of magmatic differentiation, such as Th/Sc, La/Sc, Th/Cr, Eu/Eu* $\left(r^{2}=0.39,0.41,0.23\right.$, and 0.26 , respectively); and almost linear correlations between the CIA and PIA values ( $\mathrm{KRG}: r^{2}=0.97$; KRG: $\left.r^{2}=0.94\right)$.
The extreme components in the mixing scenario for the KRG assembly, following the A-CN-K diagram, are samples 67 , 73,68 on the $\mathrm{CN}$ side (with $\mathrm{P} / \mathrm{F}=73 \%, 70 \%$, and $67 \%$, respectively), and K-feldspar- (nos. 64, 62; with $\mathrm{P} / \mathrm{F}=44 \%$ and $46 \%$, respectively), dacite- (no.70) and muscovite-bearing (no. 69) samples from the $\mathrm{K}$ side of the diagram. The $\mathrm{CN}$-rich samples, according to the A-CN-K diagram, indicate tonalite to granodiorite composition of the source. This component fits well to andesites and trachytes dominant in the clast spectrum of these samples. The opposite component may be identified as: (1) dacite occurring as clasts in the sample 70, and (2) older sedimentary rocks - the additional K-enrichment from this 

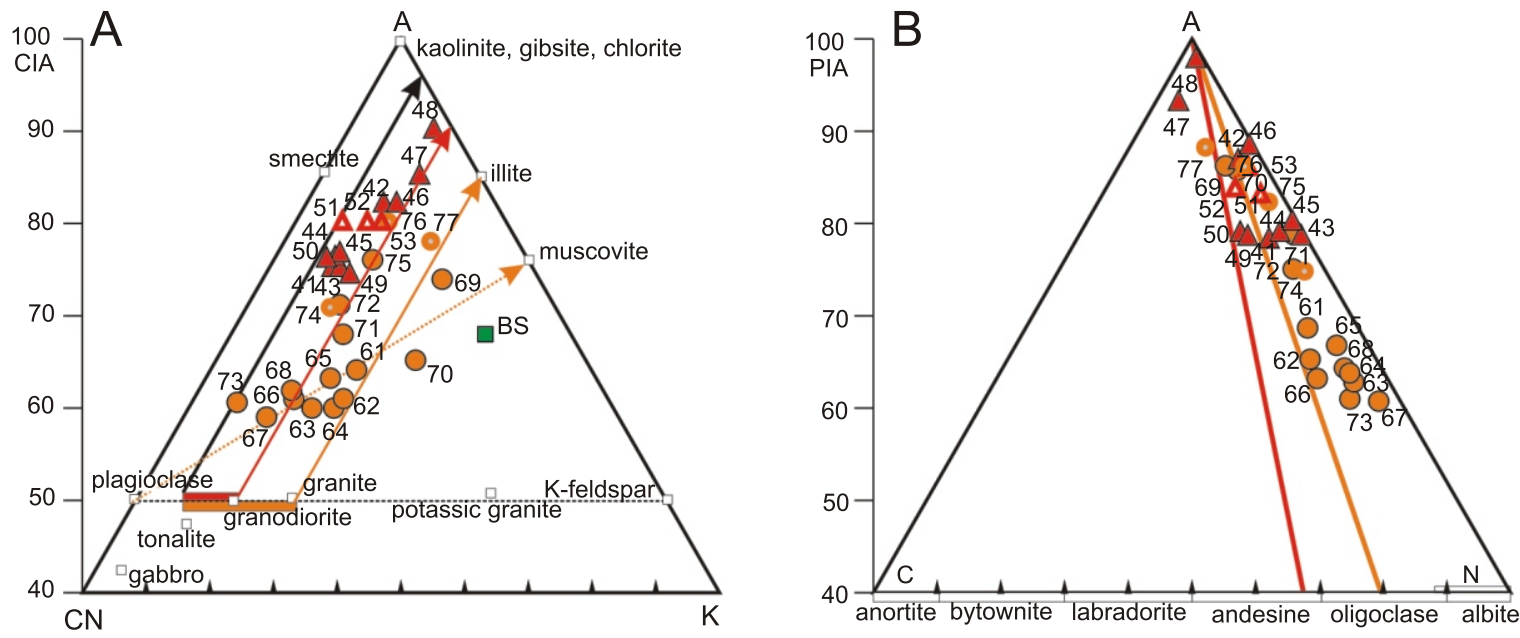

Fig. 11. A-CN-K (A) and A-C-N (B) ternary diagrams of molecular proportions of $\mathrm{Al}_{2} \mathrm{O}_{3}(\mathrm{~A}), \mathrm{CaO} *(\mathrm{C}), \mathrm{Na}_{2} \mathrm{O}(\mathrm{N})$ and $\mathrm{K}_{2} \mathrm{O}(\mathrm{K})$ for the Silurian greywackes of the Holy Cross Mountains (using the method of Fedo et al., 1995; Nesbit and Young, 1982, 1984)

CIA values increase from around 50 for the fresh magmatic rocks to 100 for the most weathered rocks (Fedo et al., 1995); solid arrows show predicted weathering trends of tonalite, granodiorite and granite source composition; other explanations as in Figure 1

source type is probably due to a high muscovite admixture and its enrichment in the matured quartz arenites, due to sorting (samples: KRG no. 69, ŁRG nos. 47 and 48).

Mixing of the more matured, muscovite-bearing (?local) source and volcaniclastic (exotic) sources of trachyte/andesite to dacite composition, in the formation of the studied greywackes is manifested in a very wide spectrum of REE pattern variants. The variants (Fig. 10) are compatible in both sample suites, reflecting the presence of similar components and indicating the consistent source area for the KRG and the ŁRG. However, it is important to note that the presence of similar source components does not exclude their variable proportions in the formation of the two suites (see below).

Some of the samples in both groups show a flat-fractured PAAS-normalized REE pattern (Fig. 10C), similar to the Lower-Middle Cambrian rocks of the Kielce Region (however, with a slightly lower Eu anomaly). Another group of samples, representing relatively quartz-rich rocks in both study areas, has REE patterns (Fig 10D) indicating a close similarity to the Bardo sandstone (Llandoverian of the Kielce Region) and the Furongian of the Łysogóry Region. However, again, a relatively lower Eu anomaly is observed in the Ludlovian rocks. These samples contain abundant detrital muscovite with similar multigrain K-Ar cooling ages noted in both sample suites (KRG: $724 \pm 27$ and ŁRG: $738 \pm 38 \mathrm{Ma}-$ Kozłowski et al., 2004; Nawrocki et al., 2007), as well as in the detrital muscovite age spectrum for the Furongian of the Łysogóry Region (Belka et al., 2002; Nawrocki et al., 2007). Both variants of REE patterns mentioned above (Fig. 10C, D) may indicate an important admixture (or even local dominance) of detritus from the uplifted and exhumed substratum of the basin, supplied to both areas. The third group of samples (Fig. 10E, F) shows distinct similarities to the average andesite (Fig. 10E) and the Stawy bentonite (Fig. 10F) regarding their REE patterns, thus representing a relatively pure volcanoclastic component.

On the background of the KRG sample pattern on the A-CN-K diagram, the $Ł R G$ pattern may be interpreted as similar mixing between a muscovite-bearing (?local) source (muscovite-rich sample no. 48) and a relatively more consistent volcaniclastic (exotic) component. The narrower (tonalite to granodiorite) composition (Fig. 11A) of the volcaniclastic component of the $\measuredangle R G$ is confirmed by differences visible in the volcanic clast spectrum, with a distinctly higher contribution of trachytes, less frequent andesites and extremely rare dacites in the $Ł R G$ suite compared to the KRG.

In the case of the source area comprising various rock types, the compositional homogeneity of the detritus between separate beds should increase during the multiple reworking of the sediments. Thus, the petrographical and geochemical homogeneity may be an indicator of the degree of reworking. The ŁRG shows a higher homogeneity than the KRG in both the petrographic and geochemical analyses, as reflected, e.g., in the lower standard derivations of their provenance proxies: $\mathrm{Th} / \mathrm{Sc}, \mathrm{La} / \mathrm{Sc}, \mathrm{Rb} / \mathrm{Sr}$ or Eu/Eu* ratios. Hence the $\measuredangle R G$ may be considered as sediments with a higher degree of reworking in relation to the KRG.

\section{TERRANE TYPE}

A widely used indicator of the source terrane type is the modal composition of greywackes, along with the analysis of extraclast lithology. On the discriminate plots of Dickinson et al. (1983; Fig. 12 - presented earlier in Kozłowski et al., 2004), the less mature material of the KRG is located generally within the recycled orogen field, but close to and also partially inside the volcanic arc field. The more mature detritus of the ŁRG is located in the recycled orogen field. The linear pattern of the samples, extending from the volcanic arc sector to the quartzose recycled orogen sector of the diagrams (Fig. 12A, B, D), indicates a volcanic arc terrane as an important component of the source, with (probably multiple, in some cases) recycling and/or reworking of part of the material, and/or variable admixture of more mature material. The Qp-Lv-Lsm (Fig. 12C) plot of Dickinson (1985) is used to distinguish between the main orogen types. Samples of both suites spread between the collision and arc orogen source, with a large number of samples located between the arc orogen and the subduction complex field. This is suggestible for the mixing between these two provenance com- 


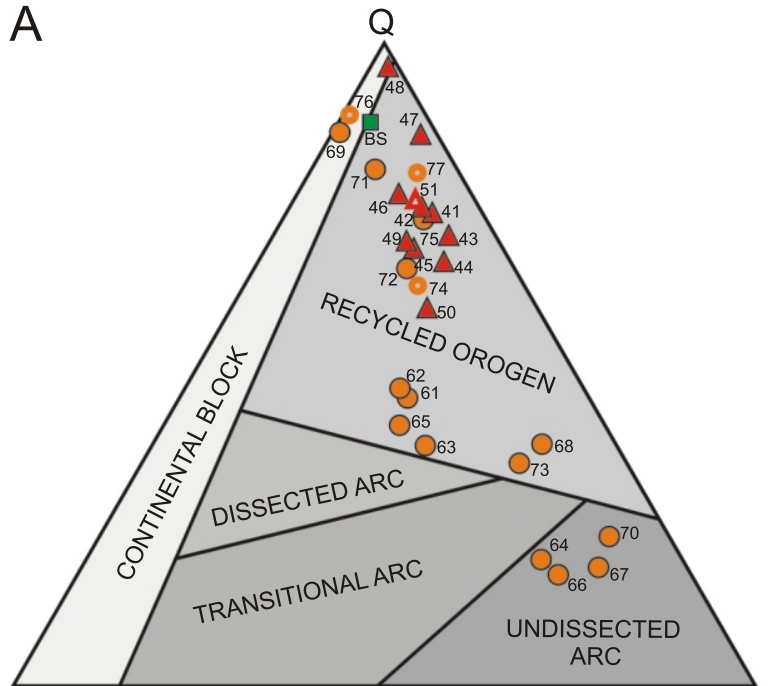

$\mathrm{F}$

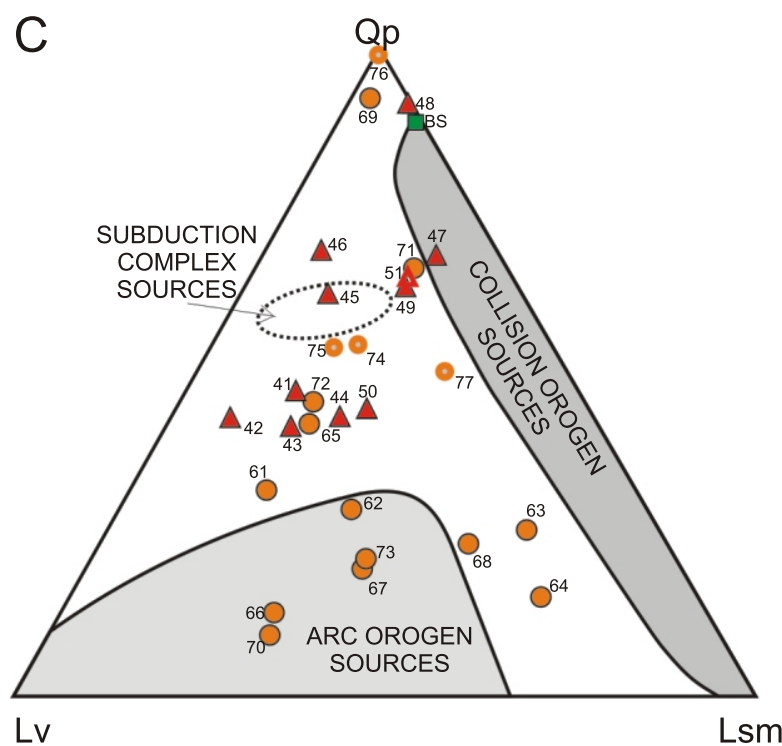

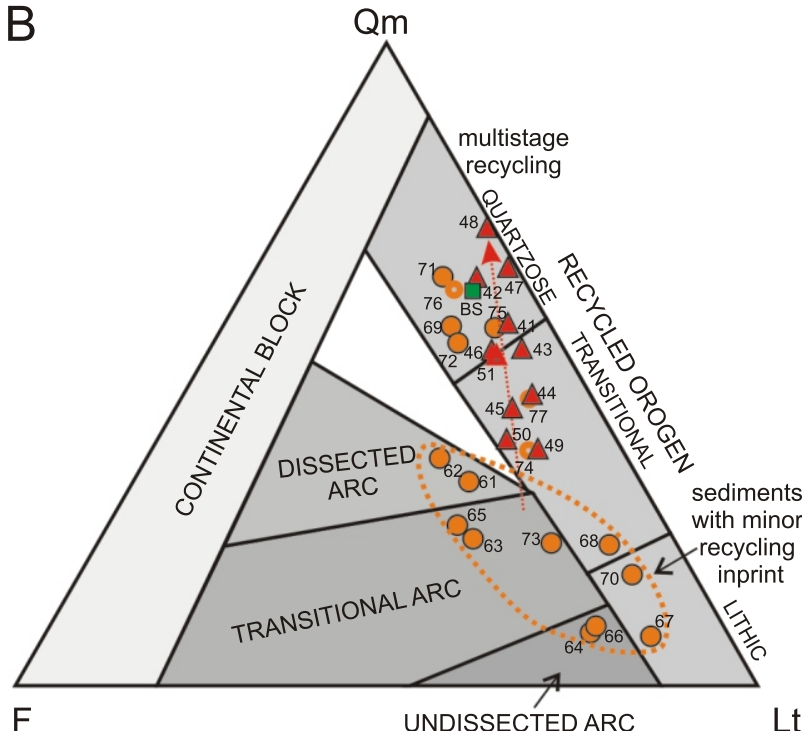

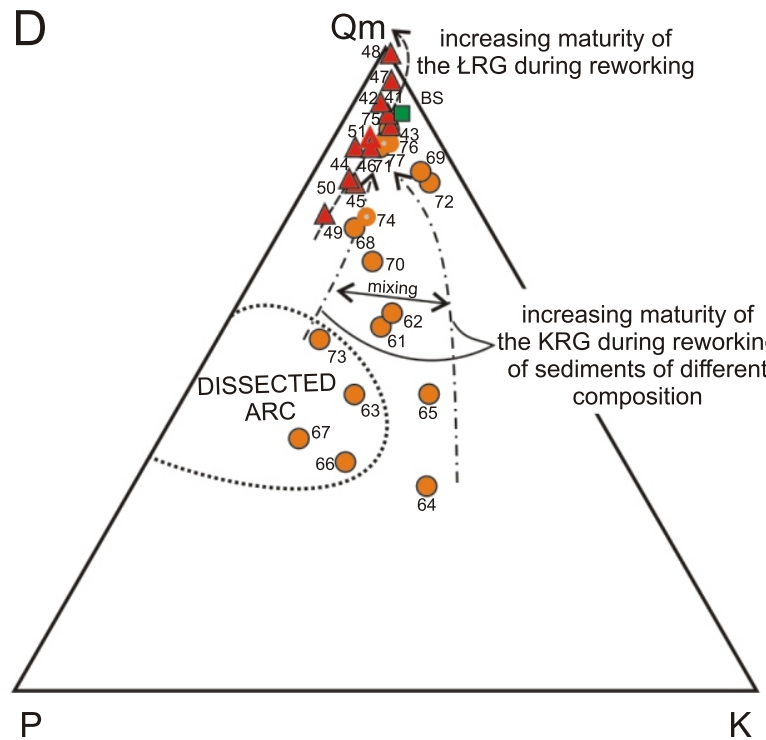

Fig. 12. Source terrane type discrimination ternary diagrams for the studied sediments (presented earlier in Kozłowski et al., 2004; discriminate fields after Dickinson, 1985)

F - feldspar, K - K-feldspar, L - lithoclasts, Lsm - sedimentary clasts, Lt - total lithics, Lv - volcanic clasts, P - plagioclase, Q - quartz, Qm - monocrystalline quartz, Qp - polycrystalline quartz including cherts; other explanations as in Figure 1

ponents, with even some dominance of the subduction complex provenance component in the case of the ŁRG.

These features may suggest that the Silurian greywackes of the $\mathrm{HCM}$ are not the first-cycle sediments, which is also confirmed by high amounts of sedimentary (mainly cherts and wackes) and metasedimentary clasts (mainly metamorphosed wackes and siltstones with lesser quartzites). On the other hand, the high amount of the fresh volcanic component (e.g., abundant automorphic biotite flakes and angular quartz grains with resorbed margins) and relatively low $\mathrm{CIA}$ values in part of the KRG samples, suggest a significant contribution of the original volcanic arc rocks, and/or first cycle volcaniclastic (circum arc) sediments, to the formation of the KRG suite, if not both regions.

The dominance of a recycled sediment source of the studied sedimentary rocks is also observed in the method of function analysis of major elements of Roser and Korsch (1988). As in the case of modal composition analysis, the less altered $\mathrm{CN}$-rich sample of the KRG shows a dominance or an important admixture of detritus from felsic and andesitic sources (Fig. 13). In the same discriminant diagram, the ŁRG samples lie mostly within the recycled sediment sector of the diagram, however, with their trend starting from the mafic sector of the diagram. This mafic component is not confirmed by the characteristics of trace elements (see below), and may be attributed to the early diagenetic enrichment in $\mathrm{Fe}_{2} \mathrm{O}_{3}$. In order to test it, we assumed that in the case of a significant contribution of the potential mafic component, the $\mathrm{Fe}_{2} \mathrm{O}_{3}$ enrichment should be related to higher $\mathrm{MgO}$ abundances. Hence, in our calculations we substituted the $\mathrm{Fe}_{2} \mathrm{O}_{3}$ abundance by the amount calculated from the $\mathrm{MgO}$ content, according to its average ratio in the less altered samples. After this correction, the bulk of $Ł R G$ samples are placed in the recycled sediment field of the diagram (not shown), what contradicts the significant influence of the mafic source in the studied case.

Several trace elements and REE are very good indicators of sediment provenance because of their immobility in surface 


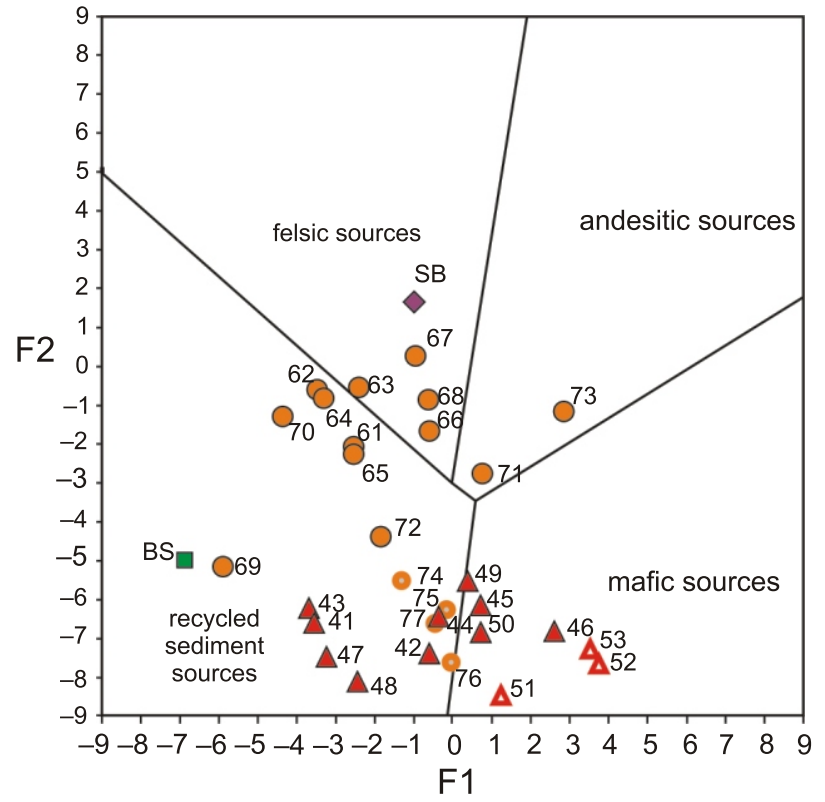

Fig. 13. Discriminant plot of source rock types for the Upper Silurian greywackes from the Holy Cross Mountains, based on discriminant functions of main oxides abundance (after Roser and Korsch, 1988)

Note distinct similarities of samples distribution with the A-CN-K diagram (Fig. 11) and the Dickinson ternary diagrams (Fig. 12); other explanations as in Figures 1 and 2

conditions and low residence time in sea water (Bhatia and Crook, 1986; McLennan, 1989; McLennan et al., 1993). The most important geochemical indicators of terrane types are the $\mathrm{Th} / \mathrm{Sc}, \mathrm{Th} / \mathrm{U}, \mathrm{Eu} / \mathrm{Eu}^{*}$ ratios, and the REE pattern (McLennan et al., 1993).

The Th/Sc ratio is a widely used index of the igneous differentiation of a source. It is based on the incompatibility of Th and high compatibility of Sc in igneous systems (McLennan et al., 1993). Because of the immobility of both elements, the Th/Sc ratio is a very good indicator of the average provenance, with typically upper continental crust values higher than 0.79 (McLennan, 2001). On the other hand, during multiple recycling, the $\mathrm{Th} / \mathrm{Sc}$ ratio also increases due to zircon enrichment and quartz dilution. However, this process may be monitored by a combination of the $\mathrm{Th} / \mathrm{Sc}$ ratio with the $\mathrm{Zr} / \mathrm{Sc}$ ratio. In the case of the dominance of the sediment recycling process, the $\mathrm{Th} / \mathrm{Sc}$ ratio is more consistent than the $\mathrm{Zr} / \mathrm{Sc}$ ratio (McLennan et al., 1993). The sample distribution pattern on the $\mathrm{Th} / \mathrm{Sc}$ versus $\mathrm{Zr} / \mathrm{Sc}$ diagram (Fig. 14A) indicates a moderate influence of recycling, however, with high dispersion of the KRG samples around the oblique recycling line. It may point to a wide range of compositional variations of the $\mathrm{Th} / \mathrm{Sc}$ ratios in the primary source (McLennan et al., 1993). A lower than the average UCC (0.79 - value after McLennan, 2001) and highly variable Th/Sc values indicate a significant input of young depleted crust material with a felsic to andesite composition (McLennan et al., 1993). The $Ł R G$ sediments show, in contrast, a more horizontal pattern on the diagram, with a more consistent $\mathrm{Th} / \mathrm{Sc}$ ratio. The average $\mathrm{Th} / \mathrm{Sc}$ ratio $(0.85)$ is typical of the UCC, however, mini$\mathrm{mal} \mathrm{Th} / \mathrm{Sc}$ ratio values in the $Ł R G$ also indicate some influence of a less differentiated component, despite a significantly higher imprint of recycling in the case of the $Ł R G$ suite.

Another robust indicator of provenance is the Th/U ratio. The primary $\mathrm{Th} / \mathrm{U}$ ratio depends on the composition of source areas, with typical values $>3.8$ for the old crust sources and $<3.0$ for

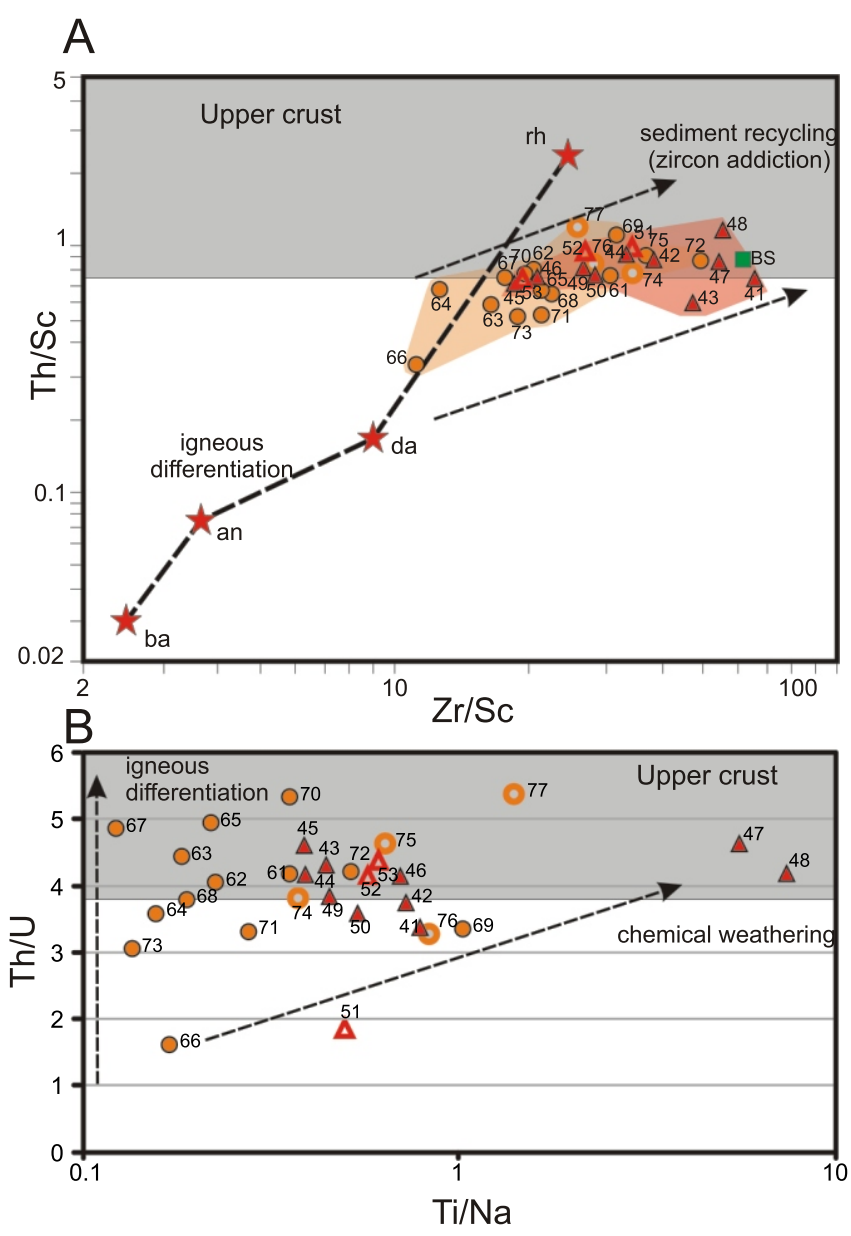

Fig. 14A - Th/Sc vs. Zr/Sc (after McLennan et al., 1993);

B - Th/U vs. Ti/Na plots for the Upper Silurian greywackes from the Holy Cross Mountains

Stars denote the average compositions of basalt (ba), andesite (an), dacite (da) and rhyolite (rh), plotted according to Roser (2000); other explanations as in Figure 1

young depleted crust (McLennan et al., 1993). During chemical weathering, detritus loses its $U$, which causes an increase of the $\mathrm{Th} / \mathrm{U}$ ratio. Hence, the high $\mathrm{Th} / \mathrm{U}$ ratios often observed in sedimentary rocks result from the interference of the weathering effect with the parent rock composition. Distinguishing between these effects may be possible with a combination of the Th/U ratio with other proxies of chemical weathering, e.g., Ti/Na ratio (Roy et al., 2008). The Th/U-Ti/Na diagram (Fig. 14B) for the studied sediments shows no correlation, high scatter, and a wide spectrum of $T h / U$ values for the samples with low values of the $\mathrm{Ti} / \mathrm{Na}$ ratio (note the consistent position of individual samples in Figs. 13 and 14). It may be caused by the wide original spectrum of the Th/U ratio (compositional variations), resembling the vertical scatter of the samples on the Th/Sc-Zr/Sc diagram. The presence of the $\mathrm{Th} / \mathrm{U}$ ratios lower than in the Old Upper Continental Crust (typically being 3.5 to 4.0 , according to McLennan et al., 1993) indicates a significant admixture of material derived from a young magmatic arc source $(<3.0$, according to McLennan et al., 1993).

Another important provenance proxy is the internal distribution of REE. In general, the REE characteristics of the studied greywackes is intermediate between that for average andesite and PAAS, and overlaps with the typical continental-arc to ac- 
tive continental margin values and ratios (McLennan, 1989; McLennan et al., 1993). The REE patterns of the samples along with the low $\mathrm{Th} / \mathrm{Sc}$ and $\mathrm{Th} / \mathrm{U}$ ratios confirm the presence of a low-differentiated component by their moderate LREE over HREE enrichment, and total REE abundances lower than the PAAS. The Eu anomaly in the KRG and $Ł R G$, distinctly lower than in typical craton-derived sediments, also confirms this interpretation.

The volumetric dominance of the basic to intermediate source component in the sedimentary rocks is often manifested in a high La/Th ratio (Floyd and Leveridge, 1987), and enrichment of $\mathrm{TiO}_{2}$ in relation to $\mathrm{Al}_{2} \mathrm{O}_{3}$ (Girty et al., 1996) and $\mathrm{Zr}$ (Bhatia and Crook, 1986). The La/Th ratios, only in part above 3 (2.43-3.66 for the ŁRG and 2.28-3.7 for the KRG), along with the lack of the prominent enrichment of $\mathrm{TiO}_{2}$ in relation to $\mathrm{Al}_{2} \mathrm{O}_{3}$ and $\mathrm{Zr}$, do not indicate the volumetric dominance of the low-differentiated component of its source.

Ferromagnesian trace elements $(\mathrm{Cr}, \mathrm{V}$, and $\mathrm{Ni})$ may be useful for tracing the admixture of the oceanic crust or mafic material in the composition of the sedimentary rocks. The enrichment of $\mathrm{Cr}$ over other ferromagnesian elements represented by $V$ is often used as an indicator of detrital chromite in the heavy mineral spectrum. According to McLennan et al. (1993), the ophiolite component would have the $\mathrm{Cr} / \mathrm{V}$ ratio above 10, parallelly with a low $\mathrm{Y} / \mathrm{Ni}$ ratio, reflecting the relation between the abundances of REE and the ferromagnesian elements.

Both of the studied sample suites show a low average $\mathrm{Cr} / \mathrm{V}$ ratio of 0.89 for the $\measuredangle R G$ and 1.04 for the KRG (UCC $=0.58$; PAAS $=0.73$ ), and low average $\mathrm{Y} / \mathrm{Ni}$ values of 0.41 for the $Ł R G$ and 0.62 for the KRG (UCC = 1.1; PAAS=0.49). These data do not support a significant admixture from the ophiolite component.

Yet another useful proxy for monitoring the mafic component is the $\mathrm{Cr} / \mathrm{Th}$ ratio (Condie and Wronkiewicz, 1990), with average values of the upper continental crust being about 3 (Totten et al., 2000). The enrichment of ferromagnesian ele-

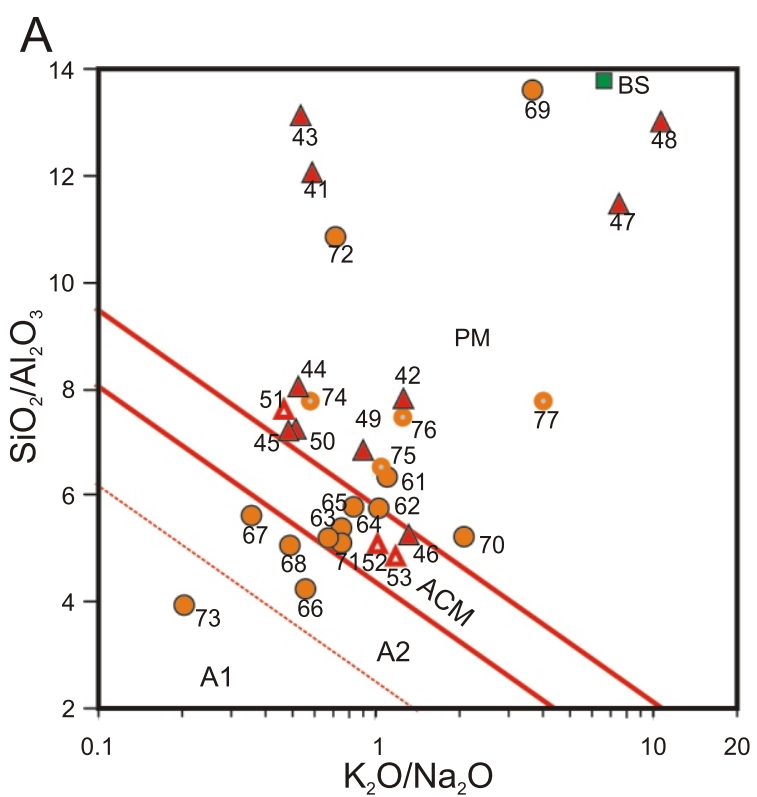

ments in the studied rocks is clearly visible in the elevated $\mathrm{Cr} / \mathrm{Th}$ ratio $(\mathrm{UCC}=3$; PAAS $=7.53$; $Ł R G$ : average value $=8.17$, max. $=19.6$; KRG: average value $=12.2$, $\max .=24.5)$. These values, along with low Y/Ni ratios for these rocks, confirm the presence of some admixture of detritus from low-fractionated source rocks (although not necessarily ophiolitic - Cullers, 1994). On the other hand, in the better-sorted $Ł R G$ suite, a strong correlation between the $\mathrm{Zr}$ and $\mathrm{Cr} / \mathrm{V}$ ratio $\left(r^{2}=0.74\right)$ may suggest the presence of chromian spinels in the heavy mineral spectrum. Within the KRG suite, the abundances of $\mathrm{Cr}$, Ni, Co, $\mathrm{V}$, and Sc are positively correlated with the $\mathrm{MgO}$ abundances, likely suggesting an admixture of a weathered ultramafic component (Kamp and Leake, 1995).

\section{TECTONIC SETTING}

Immobile trace elements are very useful as indicators of the source terrane type. However, the deposition of sedimentary rocks may be very distant in time from the process that formed their source. The immobility of trace elements causes conservation of the geochemical signature of the tectonic setting, in which the parent source rocks were formed. Hence, the tectonic environment of deposition should be interpreted mainly based on the elements/components with faster evolution in the geological record, i.e., the petrographic composition, ratios of some major mobile elements and spectrum of rock alteration indices. The tectonic setting is often also well recognized on multi-element (including trace element) diagrams (e.g., Floyd et al., 1991; Fig. 9).

The variable degree of alteration of clastic material observed in the studied sedimentary rocks, with the high scattering around the average trend and the presence of relative low CIA values (Fig. 11), suggests non-steady-state weathering conditions, preferably occurring in an active tectonic setting (Nesbitt et al., 1997; Purevjav and Roser, 2012).

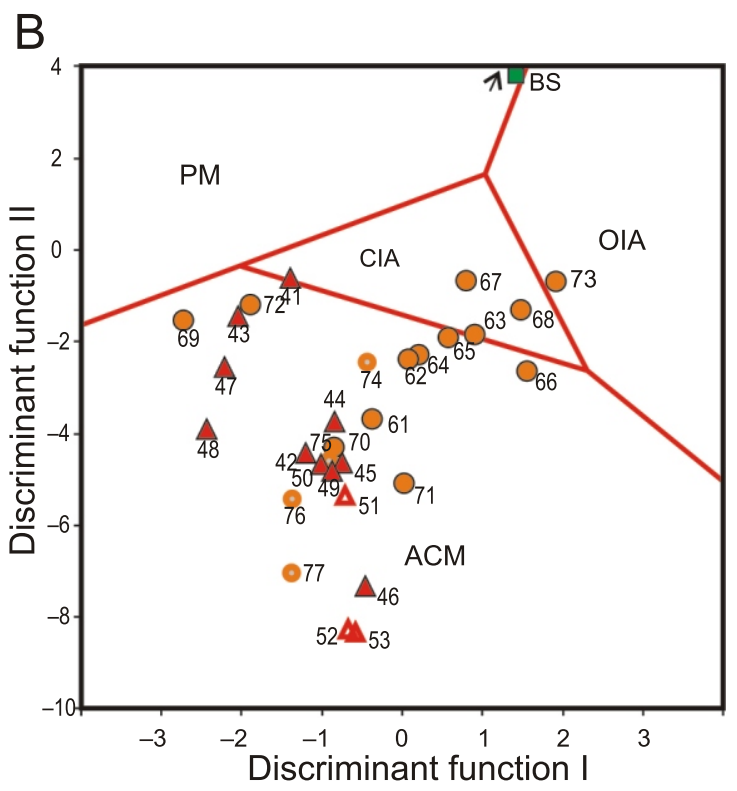

Fig. $15 \mathrm{~A}-\mathrm{K}_{2} \mathrm{O} / \mathrm{Na}_{2} \mathrm{O}$ vs. $\mathrm{SiO}_{2} / \mathrm{Al}_{2} \mathrm{O}_{3}$ discriminant plot (Roser and Korsch, 1986); $\mathrm{B}$ - diagram of the tectonic environment discrimination function based on the major element abundances (method after Bhatia, 1983) for the Silurian greywackes from the Holy Cross Mountains

A1 - arc setting, basaltic and andesitic detritus; A2 - evolved arc - felsic and plutonic detritus $\mathrm{ACM}$ - active continental margin; CIA - chemical index of alteration; OIA - oceanic island arc; PM - passive margin; other explanations as in Figure 1 
The distribution of the KRG samples on the major-element-based diagrams of Bhatia (1983) and Roser and Korsch (1986) is very similar (Fig. 15), and shows patterns linked with their CIA values. Low-altered KRG samples are located in the oceanic and continental arc sector of the diagram, whereas highly altered samples indicate an active to passive margin setting. These results are in accordance with the sample pattern of modal composition diagrams, with their position being in good correspondence to the particular samples.

Based on this, the active to passive continental margin distribution of the ŁRG samples on the major-element-based discriminant diagrams (Fig. 15) is probably also attributed to their differential recycling (not first-cycle sediments) and the original source of their parent deposits can probably be linked with an active continental margin.

The multi-element diagram normalised to the Upper Continental Crust, when compared to the crust-normalized abundances of selected elements in the Paleozoic sedimentary rocks from known tectonic settings, may also serve as a very useful tectonic setting discriminator (Floyd et al., 1991). On the diagram (Fig. 9), the less-altered part of the KRG suite (Niewachlów Formation) shows a dominance of the features referring to the active continental margin [K-Ba near the UCC abundances, low $\mathrm{Nb} / \mathrm{Nb}^{*}$ anomaly (av. 0.26 ), a pronounced V-Cr-Ni-Ti-Sc positive anomaly, La-Th and Cs depletion]. On the other hand, the pronounced negative $\mathrm{Sr}$ anomaly and the moderate enrichment in elements related to heavy minerals, suggest some reworking of the material, which is typical for passive margin sediments. The more highly altered, upper part of the KRG (Kielce Beds), shows distinct geochemical similarities with the $ヒ R G$ suite. On the multi-element diagram, both rock suites show relatively more passive-margin signatures, with distinct $\mathrm{K}-\mathrm{Rb}$ depletion, stronger $\mathrm{Sr}$ depletion, relative enrichment in $\mathrm{Hf}-\mathrm{Zr}-\mathrm{Y}$ and less pronounced $\mathrm{V}-\mathrm{Cr}-\mathrm{Ni}-\mathrm{Ti}-\mathrm{Sc}$ enrichment. The $\mathrm{Nb} / \mathrm{Nb}^{*}$ anomaly is similar, with a mean of 0.23 .

\section{DISCUSSION}

\section{PALAEOGEOGRAPHIC SETTING}

From the perspective of Silurian palaeogeography, Łysogóry, Małopolska and the marginal part of the East European Craton (EEC) may be considered as parts of a single continuous continental crust domain. The Baltica-Małopolska unity, at least since Ordovician times, is confirmed by consistent Silurian and Ordovician palaeopoles (Nawrocki, 2000; Schatz, 2006) and a Baltic-type Ordovician fauna known from the Kielce Region (Dzik and Pisera, 1994; Cocks, 2002). The Early Paleozoic Łysogóry-Baltica connections are manifested by the very close affinities in the evolution of Furongian (Upper Cambrian) trilobite fauna (Żylińska, 2002) and typical of Baltica $\mathrm{K}-\mathrm{Ar}$ multigrain ages of detrital muscovite in Cambrian rocks of the Łysogóry Region (Belka et al., 2002; Nawrocki et al., 2007). According to Kozłowski (2008), the common development of a Silurian foreland basin succession confirms the adjacency of these areas at the time of Caledonian accretion (Fig. 1A; Table 1). It is important to note that earlier, Narkiewicz (2002) had assigned the Łysogóry Basin to the Caledonian foreland; however, he postulated a stable cratonic position of the Kielce Region and a post Silurian-pre-Emsian right-lateral translation of both domains. This interpretation has been based on the postulated differences in the thermal history of both terranes and their different subsidence history (Narkiewicz, 2002). The first argument is less essential because a consistent thermal maturity pattern occurs up to at least the Upper Devonian and is not present only in the Triassic rocks around the HCM inlier (Narkiewicz et al., 2010: fig. 11). Present knowledge (Narkiewicz et al., 2010) indicates that the pattern is likely common for both blocks (gradual increase from the south to the north across both domains), hence the thermal event responsible for its creation, post-date eventual translation of the Holy Cross terranes.

More crucial is the attempt to compare the Silurian subsidence history between Małopolska and Łysogóry. The first problem in this aspect is the thickness of the Upper Silurian rocks, adopted in the model. Narkiewicz (2002) used the minimal estimations of the thickness for the interpreted variant of his model (see discussion in Kozłowski, 2008: p. 69-70), whereas the maximum known thickness (Tomczyk, 1954, 1974: fig. 13; Pożaryski and Tomczyk, 1993: fig. 15) was not mentioned. The second problem is the lack of precise time calibration in the Upper Silurian of the Kielce Region, because the entire greywacke succession represents exclusively the Bohemograptus bohemicus Zone (probably incomplete at the top). Summing up, it cannot be excluded that the Silurian Małopolska Basin, before its inversion, might even have had a higher subsidence ratio in comparison to the Łysogóry Basin.

The results of the above-presented provenance analysis (listed in Table 1) confirm a common source for the Ludlovian greywackes from both regions and their formation inside a common foreland basin. The data strengthen also the interpretation of the postulated Silurian plate-scale unity of the Holy Cross Mountains regions since at least the Ordovician (Cooks and Torsvik, 2005; Nawrocki et al., 2007). On the other hand, the listed differences (Table 1) may be referred to the internal diversity of the foreland basin geology and need to be discussed separately (see below).

Reconstruction of the Silurian palaeogeography in the southern part of the TESZ would benefit from the comparison of the greywackes with their lateral equivalents. To the north-west of the Holy Cross Mountains (Mazovia, Pomerania; Fig 16A), the foreland infill is composed of up to a $2000 \mathrm{~m}$ thick complex of shales and siltstones (see Jaworowski, 1971, 2000). The beginning of foreland sedimentation in this area is diachronous (Jaworowski, 2000) and began in the early Wenlock in its western part (e.g., Słupsk IG-1 borehole), and in the early Ludfordian in its eastern part (e.g., Żarnowiec IG-1 borehole), which confirms the south-west derivation of the clastic material. To the south-west of the undeformed (EEP) part of the foreland, the Koszalin-Chojnice Zone represents its more proximal part (Fig. 16A), with the presence of Caledonian deformation and a Late Ordovician beginning of the foredeep infill (Podhalańska and Modliński, 2006). Provenance studies of both successions (Krzemiński and Poprawa, 2006) indicate a similar Upper Continental Crust source and passive margin signatures of the tectonic setting. Detrital zircons (Poprawa et al., 2006) show ages typical of the East European Craton, with some admixture of Cadomian and Caledonian sources, while the detrital muscovite cooling ages record a distinct imprint of Caledonian low-grade metamorphism in the source area (Poprawa et al., 2006). According to the palaeotectonic reconstruction (Poprawa, 2006: fig. 6), the Caledonian orogen in northern Poland was composed (from bottom to top) of the sedimentary cover of Baltica, Baltic crust, incorporated oceanic crust, an island arc and the crystalline basement of Avalonia. In this context, the facies, geochemistry and detritus ages in the Pomeranian segment of the foreland indicate the dominance of an older sedimentary [(or lower plate (EEP) crust)] component in the source (Krzemiński and Poprawa, 2006; Poprawa, 2006). In our opinion, the lack of a clearly identified island arc component in 
Comparison of geology and provenance of the Silurian greywackes from the Kielce and Łysogóry regions

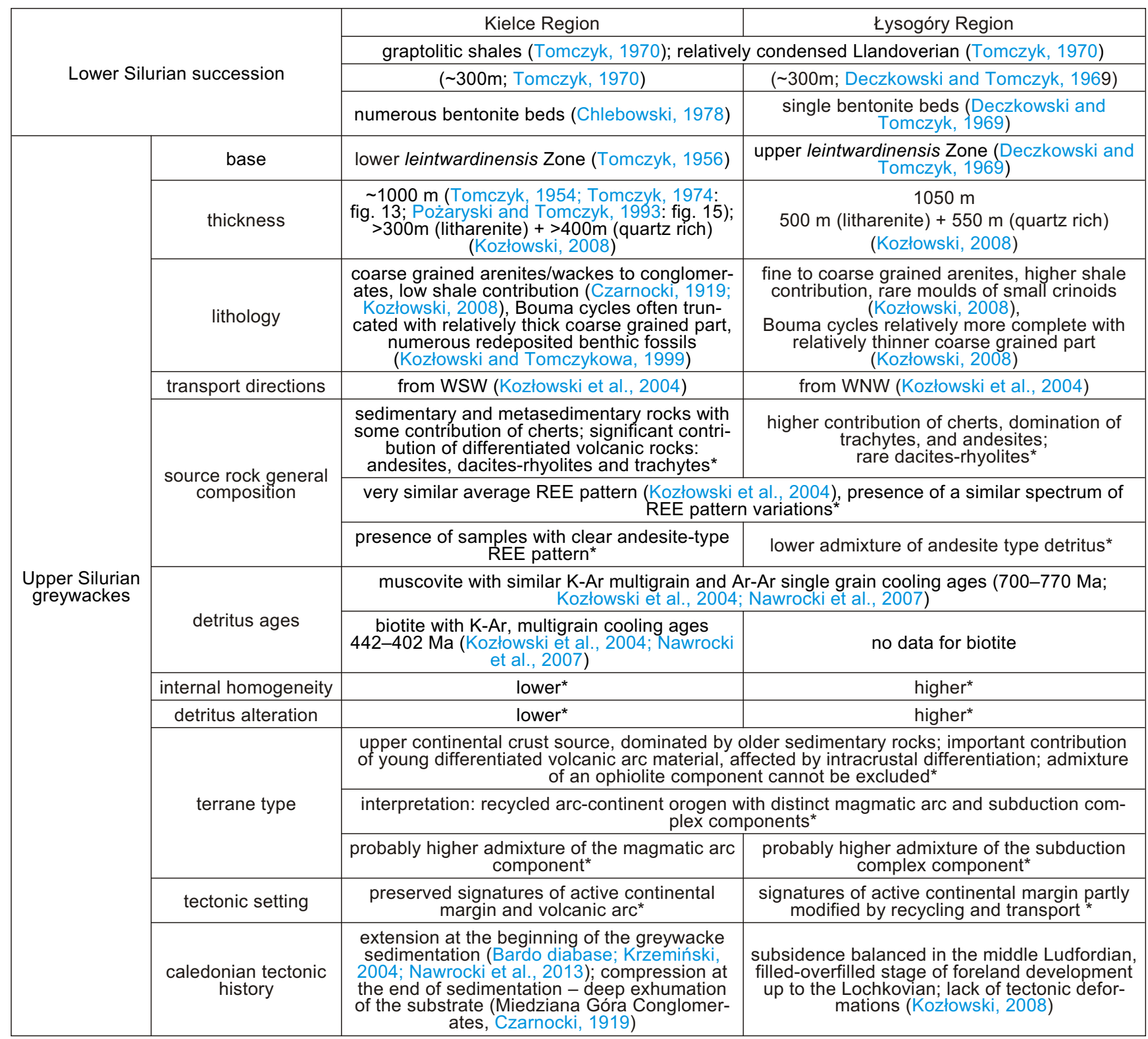

* - this study

the Pomeranian succession (Krzemiński and Poprawa, 2006), recognized in the Rügen segment of the Caledonian suture (Giesse et al., 1994; Schovsbo, 2003), can be explained by a local morphological isolation of the inner terranes by a relatively wide external zone of the orogen composed of deformed sedimentary rocks (fold-thrust belt; compare Dorsey, 1985, 1988).

To the south-west of the Holy Cross Mountains, the Caledonian foreland succession extends up to the margins of the Małopolska terrane (Fig. 16A). The most proximal facies of the foreland infill (Łapczyca conglomerates and greywackes Buła, 2000) appeared near the Kraków-Lubliniec strike-slip zone (border between the Małopolska and Upper Silesia terranes).The Upper Silesia block has a Cadomian consolidation of the basement and lacks traces of Caledonian volcanic and/or tectonic activity (Buła et al., 1997). Because the clast spectrum in the Łapczyca Formation does not correspond to the pre-Devonian substratum of Upper Silesia (Buła, 2000), the juxtaposition of Małopolska against the Upper Silesia terrane is questionable. Hence, the Silurian palaeogeography beyond the Kraków-Lubliniec Zone needs to be reconstructed on the basis of the Małopolska-Łysogóry Caledonian foredeep infill and its tectonic history.

\section{RECONSTRUCTION OF THE SOURCE AREA}

According to the provenance analysis, both Upper Silurian basins of the HCM have a very similar, recycled orogen type source, located to the west and south-west of the Małopolska and Łysogóry terranes (present coordinates). Detritus derived from this source differs from the older clastic sedimentary rocks 


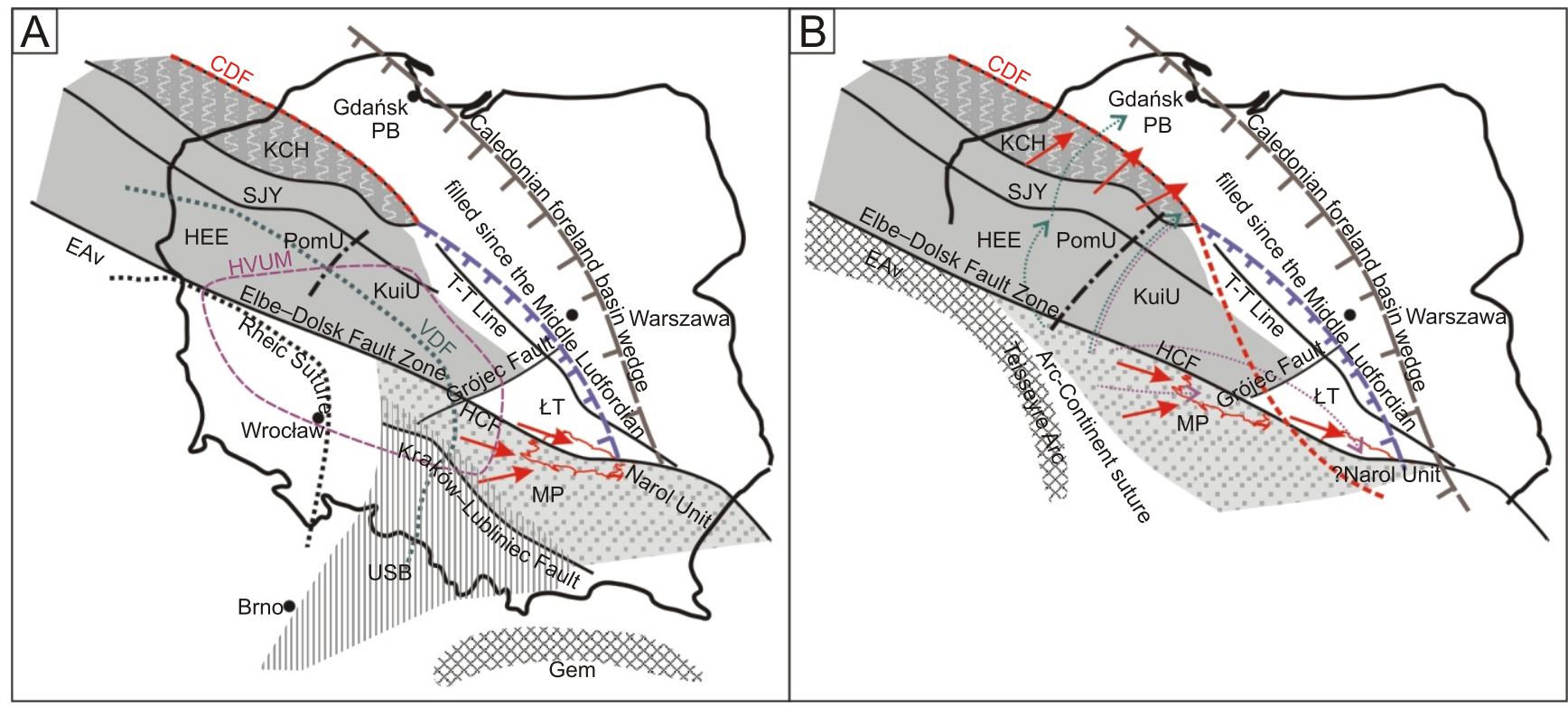

Fig. 16A - Caledonian terranes (present in the lower layer of the crust) on the southwestern margin of the East European Craton and the main tectonic lineaments with a probable pre-Variscan foundation (based on Oczlon et al., 2007; Narkiewicz et al., 2011, lateral extent of the Caledonian foreland facies after Jaworowski, 1971; Kozłowski and Munnecke, 2010 and references therein); B sketch of interpreted Late Silurian paaleogeography during the docking of the Teisseyre Arc to the southwestern margin of the EEP

Proximal Baltica terranes in the lower layer of the crust after Oczlon et al., (2007): SJY - South Jylland Terrane, HEE - Holstein-East Elbe; prpoximal Baltica terranes in the lower layer of the crust after Janik et al. (2005) and Narkiewicz et al. (2011): PomU - Pomeranian Unit, KuiU - Kuiavian Unit; EAv - East Avalonia; HCF - Holy Cross Fault; KCH - Koszalin-Chojnice Zone (external part of the fold-thrust belt overthrusted on the EEP margin); ŁT - Łysogóry terrane (distal foreland); MP - Małopolska terrane (proximal foreland); PB - Pomeranian Basin (distal foreland); USB - Upper Silesia; VDF - Variscan deformation front;, red arrows represent general transport directions of clastic material; green arrows illustrate the possible track of Cadomian detritus (probably recycled) reported from Pomerania (Poprawa et al., 2006); violet arrows illustrate the possible track of detritus with $\sim 730 \mathrm{My}$ ages - interpreted as related to the Rodinia breakup heating event (reflected also as HVUM area in A - Janik et al., 2005); Narol Unit in the interpretation represents the part of the Małopolska terrane with a pre-Silurian facies record similar to the Łysogóry terrane; lateral extent of HVUM (high velocity upper mantle) and "Narol Unit" after Janik et al. (2005)

of the HCM. The Cambrian-Ordovician sandstones vary in the geochemical and petrological composition (e.g., Jaworowski and Sikorska, 2006; Nawrocki et al., 2007), as well as the multigrain K-Ar cooling ages of the detrital muscovite (Belka et al., 2002; Nawrocki et al., 2007). The petrographic and geochemical compositions of the Llandoverian Bardo sandstone indicate its recycled sedimentary rock source and a passive margin tectonic setting of sedimentation. The detrital muscovite has a multigrain K-Ar cooling age of $561 \mathrm{Ma}$ (Nawrocki et al., 2007), which is close to the ages commonly noted in the Cambrian rocks of the Małopolska terrane (Belka et al., 2002; Nawrocki et al., 2007). The stratigraphic position of the sandstone correlated with the sea level lowstand (cf. Johnson, 2006) and its provenance signatures suggest that its source was probably a temporarily emergent local sedimentary substratum.

According to the results of our study, the source area for the Silurian greywackes was an orogen built of a number of components, manifested in both studied suites by a wide range of clast lithology, a diverse modal composition, as well as a high spectrum of single sample geochemical variations (e.g., REE patterns, Fig. 10).

The most proximal source components were probably represented by the exhumed sedimentary cover and the basement crust of the marginal part of the Małopolska and/or the Łysogóry terranes (external fold-and-thrust belt of the orogen, cf. Poprawa et al., 2006). The REE patterns of several samples from both suites are very close to those known from the Cambrian rocks of the Małopolska terrane and the Bardo sandstone
(Fig. 10 C, D). The source is also confirmed by abundant redeposited acritarchs of Ordovician and Early Silurian age reported from the KRG (Stempień, 1990). The propagation of this large-scale uplift in the thrust zone is also documented by the clast spectrum of the Miedziana Góra Conglomerates, deposited on the top of the foreland succession in the western part of the Kielce Region (Czarnocki, 1936) and composed of rocks similar to the local substratum.

Another lower plate-related component is probably represented by the several metre thick quartz arenite complex in the middle part of the Niewachlów Beds (sample no. 69, old quarry in Niestachów). The complex is petrographically and geochemically contrasting with the rest of the Niewachlów greywackes and contains very abundant coarse muscovite with single grain Ar-Ar cooling ages of $732 \pm 3 \mathrm{Ma}$ (Nawrocki et al., 2007). The admixture of detrital muscovite with a very similar multigrain $\mathrm{K}-\mathrm{Ar}$ age is also noted in other parts of the greywacke succession in both HCM regions (Kozłowski et al., 2004; Nawrocki et al., 2007); however, the muscovite is very rare in beds dominated by volcaniclastic material (rich in large biotite flakes - see below). A similar age of detrital zircon (3 grains) has been obtained from the Caradocian of the Koszalin-Chojnice Zone (Poprawa et al., 2006). This consistent signal was referred (Nawrocki and Poprawa, 2006; Nawrocki et al., 2007) to the theoretical Wielkopolska terrane accreted during the Caledonian event. The present study shows that the REE pattern of the Niestachów sandstone (69- Fig. 10D) is very similar to that of the Bardo sandstone. Moreover, similar ages of the detritus 
(700-770 Ma), not connected with the Caledonian accretion, occur in the synrift succession of the EEP (Semenenko, 1968), the Cambrian of Pomerania (Poprawa et al., 2006) and the Holy Cross Mountains (Belka et al., 2002; Nawrocki et al., 2007). The cooling ages of muscovite from the greywackes could be attributed to the tectonothermal event of breakup of the Rodinia palaeocontinent along the Tornquist lineament (Poprawa et al., 2006; Żelaźniewicz et al., 2009). Hence, the abundant quartz-muscovite component probably represents an exhumed low-grade metamorphic basement of the marginal part of the lower plate (former Baltica).

The Ludlovian greywackes contain also an abundant admixture of volcanic rock detritus with young depleted crust signatures (Figs. 10E, F and 14). At this moment, we have no unequivocal evidence for the Caledonian age of this detritus ( $\mathrm{Nd}$ isotope signatures, single clast dating); however, the abundant detrital euhedral biotite crystals with $\mathrm{K}$-Ar multigrain cooling ages of 442-402 Ma (Kozłowski et al., 2004; Nawrocki et al., 2007) seem to be related to the stratigraphic position of the bentonites in the pre-collisional succession (very similar euhedral biotite crystals are present also in the bentonites themselves, e.g., illustrated in Langier-Kuźniarowa and Ryka, 1972). Moreover, REE patterns similar to the Stawy bentonite are noted in single samples of both studied suites (Fig. 10F). The volcaniclastic material may correspond to the island arc component, or represent the recycled filling of a forearc basin incorporated into the orogen. In the first case, increasing dissection of the arc terrane could be recorded in the foreland sedimentary succession. This scenario is not confirmed by the evolution of durable provenance proxies (petrology, major elements), which gradually change from an active (volcanic arc) to passive (recycled orogen) signatures in the Silurian succession in both areas (particularly KRG). In our interpretation, at the beginning of the greywacke sedimentation, the initial prominent relief had caused rapid influx of first-cycle arc-related detritus from a deformed and elevated forearc basin. At that stage, the proximity of redeposition caused only minor changes in the petrographic and geochemical composition of the detritus. Hence, the lower part of the succession could largely inherit the geochemical composition (and in part also petrographic) of the pre-collision arc-related setting. Thus, the upper parts of the successions in both regions (i.e., Kielce Beds, Trochowiny Formation) may be attributed to cannibalistic sedimentation and gradual peneplenization of the suture zone (cf. Dorsey, 1988). The prograding maturation of the detritus could gradually erase the active setting signatures.

Another exotic component of the reconstructed orogen is probably represented by abundant cherts, which could be derived from the incorporated accretionary prism. Some enrichment in ferromagnesian trace elements may suggest admixture of weathered ultramafic material; hence admixture of an ophiolite-related component cannot be excluded.

\section{MODEL OF PALAEOGEOGRAPHIC EVOLUTION}

According to current knowledge, the northern part of the Tornquist Ocean, which separated Avalonia from Baltica, closed in the Hirnantian (Torsvik and Rehnstrom, 2003). The initiation of the foreland basin sedimentation successively propagated to the southeast of the TESZ, which is suggested by the obliquity of the final closure of the oceanic domain (Torsvik et al., 1996; Jaworowski, 2000).

In the southern part of the TESZ, during the Late Ordovician and Early Silurian, the Łysogóry and Małopolska terranes probably formed the marginal part of the former Baltica shelf
(Narkiewicz, 2002; Cocks and Torsvik, 2005; Nawrocki et al., 2007). The area was distal to the main continental landmasses from the one side, whereas from the other side it was isolated by a still existing oceanic remnant from the exotic terranes. This situation is expressed in the slow sedimentation of the partly condensed, dark graptolitic shales in the region (Tomczyk and Tomczykowa, 1976; Masiak et al., 2003), interrupted only by one known episode of coarse-grained deposition - the Bardo sandstone bed. Bentonite intercalations, increasing in frequency and thickness towards the top of the succession (Ryka and Tomczyk, 1959), may indicate the approaching of subduction-related volcanic centres, which, however, were morphologically still isolated by the narrowing oceanic domain. In our interpretation, the narrow southern remnant of the Tornquist Ocean was bordered from the other side by a hypothetical volcanic arc termed here the Teisseyre Arc, which could be located at the southeastern margin of the Avalonian Plate.

With the beginning of the Ludlovian, the final closure of the oceanic remnants between Małopolska-Łysogóry and the Teisseyre Arc induced a change of the sedimentation regime in the foreland. The final docking of the arc caused the formation of an arc-continent orogen, a rapid change in sedimentation in the foreland and termination of volcanic activity.

The best known, actualistic model for this scenario is the Taiwan orogen (Huang et al., 1997, 2000). The orogen is composed of several terranes thrust over the continent (lower plate). The orogenic prism contains (from the bottom): accreted and deformed synorogenic sediments of the foreland basin, extensive fragments of the lower plate basement and its deformed (often low-grade metamorphosed) cover; accretionary melange with ophiolite fragments, deformed remnants of the forearc basin and the narrow zone of volcanic arc rocks. The uplift and rapid erosion of all of these components caused the catastrophic infilling of adjacent foreland basins (Taiwan Strait) by the clastic wedge (Hong, 1997), with successive gentle deformation and exhumation of its proximal parts, which are incorporated into the external part of the orogen.

Both HCM regions may be referred to the foreland basin situation in the Taiwan orogen model (Hong, 1997), because of: (1) epicratonic (Baltica) character of the underlying Cambrian-Lower Silurian succession (Szulczewski, 1996); (2) absence of traces of Silurian subduction-related magmatism on Baltica, suggesting a SW direction of Caledonian subduction; (3) the very sudden beginning of greywacke sedimentation; (4) syncollisional prograding subsidence, (5) significantly delayed in time, moderate Caledonian deformation in the Kielce Region (proximal foreland); (6) lack of Caledonian deformation and continuous sedimentation in the Łysogóry Region (distal foreland) until the Devonian.

The pre-deformational Bardo diabase intrusion in the Kielce Region (Nawrocki, 2000) with a Ludlovian age of formation (Nawrocki et al., 2007, 2013) in this context may represent a bending-flexural extension in the foreland setting (compare Lin and Watts, 2002; Lester et al., 2012).

The present-day localisation of the source for the studied rocks (southern segment of the proper Caledonian orogen) is debatable (see Fig. 16A). The Taiwan model may be very helpful in the explanation of the loss of the volcanic terrane in the post Caledonian history. It is highly probable that immediately after the collision, the Teisseyre Arc had collapsed (cf. Huang et al., 2000). Post-Caledonian relaxation of the accreted crust may have cause its extension (cf. Clift et al., 2008) and later underthrust, as a lower plate, beneath the Armorica Plate during the closure of the Rheic Ocean. Another possibility is a large scale lateral shifting of the terranes accreted during the Caledonian orogeny due to Variscan transpression (see e.g., Oczlon et al., 2007). 
RELATION BETWEEN THE KIELCE AND THE ŁYSOGÓRY REGIONS IN THE SILURIAN

For many years, the relation between the two regions of the Holy Cross Mountains in Paleozoic times has been a topic of discussions. The contrast between the Kielce and Łysogóry regions was repeatedly emphasised (e.g., Brochwicz-Lewiński et al., 1984; Tomczykowa and Tomczyk, 2000; Nawrocki et al., 2007), but the main question of the relative position in the Paleozoic has not been resolved until today.

The main differences are indicated in the pre-Silurian development of the Kielce and Łysogóry basins. In the Kielce Region (and the entire Małopolska terrane), a prominent angular Sandomirian unconformity can be observed between the Cambrian and Ordovician strata, while the unconformity is absent in Łysogóry. The differences in the Ordovician succession of both regions (Trela, 1998) may indicate a continuity of their palaeographical independence. The beginning of sedimentation of the Upper Silurian greywackes is the first clearly correlative event for both domains.

According to the lateral extent of the foreland (see above), the alimentation area was located at a significant distance, but not less than the present-day western limit of the Małopolska and Łysogóry terranes. Hence, assuming the juxtaposition of Małopolska against Łysogóry in the Silurian, converging transport directions (subparallel to the Kielce-Łysogóry boundary; Fig. 3) should result in the amalgamation and identity of the greywacke detritus between the domains. On the scale of the Holy Cross Mountains inlier, lateral facies changes along the transport directions are unnoticeable inside both facies regions. However, in an orientation perpendicular to the transport directions, the Holy Cross Fault abruptly separates contrasting facies areas. Although the petrographic and geochemical analysis indicates that the detritus from both greywacke complexes was derived from a very similar source (see above; Table 1), but some secondary dissimilarities indicate its different component contributions, alteration and reworking history. In several aspects, the KRG show lower detritus alteration than their counterparts from Łysogóry (Table 1). The relatively lower recycling of the KRG is reflected also in their lower homogeneity.

Petrographic and geochemical contrasts consistently indicate a more proximal position of the Kielce Region in comparison to the Łysogóry Region in relation to the orogen, or similar source rocks had been independently modified due to a different weathering history. The first possibility is independently confirmed by the more proximal-to-the-orogen tectonic evolution of the Kielce Region and thus more proximal facies. The initial infilling of the foreland began there earlier and was succeeded by fracturing of the basement and diabase intrusions. In the next stage, migration of the compressive regime caused overthrusting and deep exhumation of the local basement.

The facies contrasts between the KRG and $Ł R G$, along with the dissimilarities in the local foreland tectonic evolution, indicate a different distance of the two $\mathrm{HCM}$ regions in relation to the source orogen (Fig. 16B). Hence, we postulate that the Silurian position of the Małopolska terrane was to the west with regard to its present-day location. The post-Silurian left-lateral strike-slip movement to its recent location took place along the Holy Cross Fault. The scale of the postulated shift could not have exceeded the width of the foreland area, probably not over $200 \mathrm{~km}$, based on the general architecture of the basin. Accordingly, the scale of the shift is below the resolution of the palaeomagnetic method. According to Narkiewicz (2002), in his right-lateral strike-slip model, the time of the eventual translation of the HCM terranes is bracketed between the Late Ludlovian (as the time of the allegedly different subsidence) and Emsian (as the time of the "onset of uniform marginal-marine to continental clastic deposition"). Independent facies development of the domains up to the Lochkovian limits, in our opinion, the time of rebuilding from the bottom. From the top, the first undisputable uniform facies pattern across both regions took place as late as in Late Permian times (Czarnocki, 1923), because of the postulated relatively small-scale translation within a single basin, and the presence of several significant differences in the development of both domains in the Devonian (Szulczewski, 1995).

Tectonic structures along the Holy Cross Fault have recorded a right-lateral movement along this line of Late Paleozoic age (post-fold in relation to the Variscan folding; Konon, 2007). Hence, the left-lateral translation postulated herein must have been earlier.

\section{CONCLUSIONS}

1. The geochemistry and petrology of the Upper Silurian greywackes from the Holy Cross Mountains confirm (Kozłowski, 2008) their common deposition in both one Caledonian foreland basin of the southern part of the TESZ and one source segment in its hinterland, located to the west of the basin (present-day coordinates).

2. The Upper Silurian greywackes are texturally and geochemically immature and were deposited in a foreland basin of an arc-continent orogen, analogously to the present-day Taiwan foreland. According to the presented palaeogeographic model, the source area was formed due to the collision of the most external parts of the EEP (lower plate) with a volcanic arc developed on the eastern margin of the Avalonian (upper) Plate, termed here the Teisseyre Arc, during the final stage of oblique closure of the southern remnant of the Tornquist Ocean.

3. The source area consists of various terranes including fragments of a volcanic arc, circum-volcanic arc basins, an accretionary prism, and fragments of the exhumed basement of the lower (Baltica) plate and its sedimentary cover in the lowermost part of the orogenic wedge. Older sedimentary rocks and variously differentiated volcanic rocks were the source of detritus.

4. The volcanic component in the greywackes is andesite to dacite in composition and was probably formed in an evolved arc setting at a time directly preceding the sedimentation of the rocks studied.

5. In a significant part of the samples, the subduction-related geochemistry and petrography was inherited as a result of slight to moderate alteration, implying active tectonic movements at the beginning of greywacke sedimentation.

6. Greywackes from both study areas (Kielce and Łysogóry) show distinct similarities in their more alteration-resistant geochemical parameters (REE patterns, trace element geochemistry), clast spectrum, consistent ages of detrital muscovite, transport directions, timing of deposition and facies succession. These similarities indicate a common source of the greywackes in both regions of the HCM.

7. The greywackes from the Łysogóry Region show higher textural and geochemical maturity, higher sorting imprint and more consistent internal homogeneity. These features suggest their longer transport in comparison to the KRG. Based on the summarized differences between the Silurian succession of the Kielce and Łysogóry regions, we conclude that the Kielce Region represents a more proximal part of the foreland in relation to the Łysogóry Region. 
8. Contrasts in the alternation of the detritus and different sub-basin histories confirm (Kozłowski, 2008) a small- to medium-scale (below palaeomagnetic resolution), left-lateral shift of the Małopolska and Łysogóry terranes along the Holy Cross Fault after the Lochkovian and before the Late Permian. Because of the record of a Late Paleozoic right-lateral movement along the fault (Konon, 2007), the lower part of the bracketed time interval is most likely.
Acknowledgements. We are grateful to Prof. S. Skompski, Prof. E. Słaby and Dr. M. Paszkowski for their critical remarks and comments. Warm thanks are given to A. Amborski, A. Żylińska and $\nvdash$. Kruszewski for their editorial and linguistic support. The authors acknowledge anonymous reviewers for comments on the earlier versions of this manuscript. The paper reports the results of the "Paleozoic Accretion of Poland" Project, financed by MOŚ/NCN (No. PCZ-007-21).

\section{REFERENCES}

Belka, Z., Valverde-Vaquero, P., Dörr, W., Ahrendt, H., Wemmer, K., Franke, W., Schäfer, J., 2002. Accretion of first Gondwana-derived terranes at the margin of Baltica. Geological Society Special Publications, 201: 19-36.

Belousova, E., Griffin, W.L., O'Reilly, S.Y., Fisher, N.I., 2002. Igneous zircon: trace element composition as an indicator of source rock type. Contributions to Mineralogy and Petrology, 143: 602-622.

Bhatia, M.R., 1983. Plate tectonics and geochemical composition of sandstones. Journal of Geology, 91: 611-627.

Bhatia, M.R., Crook, K.A.W., 1986. Trace element characteristics of greywackes and tectonic setting discrimination of sedimentary basins. Contributions to Mineralogy and Petrology, 92 181-193.

Bock, B., Mclennan, S.M., Hanson, G.N., 1998. Geochemistry and provenance of the Middle Ordovician Austin Glen Member (Normanskill Formation) and the Taconian Orogeny in New England. Sedimentology, 45: 635-655.

Bock, B., Bahlburg, H., Worner, G. Zimmermann, U., 2000. Ordovician arcs and terranes in NW-Argentina and N-Chile? Geochemical and isotope evidence. Journal of Geology, 108: 513-535.

Brochwicz-Lewiński, W., Pożaryski, W., Tomczyk, H., 1984 Sinistral strike-slip movements in Central Europe in the Palaeozoic. Publications of the Institute of Geophysics, Polish Academy of Sciences, 160 (A-13): 3-13.

Buła, Z., 2000. The Lower Palaeozoic of Upper Silesia and West Malopolska (in Polish with English summary). Prace Państwowego Instytutu Geologicznego, 171.

Buła, Z., Jachowicz, M., Żaba, J., 1997. Principal characteristics of the Upper Silesian block and Małopolska block border zone (southern Poland). Geological Magazine, 134: 669-677.

Chlebowski, R., 1978. Petrographic studies of Early Palaeozoic tufogenic rocks from the Holy Cross Mountains (in Polish with English summary). Archiwum Mineralogiczne, 34: 126-134.

Clift, P.D., Lin, A.T., Carter, A., Wu, F., Draut, A.E., Lai, T.H., Fei, L.Y., Schooute, H., Teng, L., 2008. Post-collisional collapse in the wake of migrating arc-continent collision in the Ilan Basin, Taiwan. GSA Special Papers, 436: 257-278.

Cocks, L.R.M., 2002. Key Lower Palaeozoic faunas from near the trans-European suture zone. Geological Society Special Publications, 201: 37-46.

Cocks, L.R.M., Torsvik, T.H., 2005. Baltica from the late Precambrian to mid-Palaeozoic times: The gain and loss of a terrane's identity. Earth-Science Reviews, 72: 39-66.

Condie, K.C., Wronkiewicz, D.J., 1990. The Cr/Th ratio in Precambrian pelites from Kaapvaal craton as an index of craton evolution. Earth and Planetary Science Letters, 97: 256-267.

Condie, K.C., Noll, P.D., Conway, C.M., 1992. Geochemical and detrital mode evidence for two sources of Early Proterozoic metasedimentary rocks from the Tonto Basin Supergroup, central Arizona. Sedimentary Geology, 77: 51-76.
Cox, R., Lowe, D.R., Cullers, R.L., 1995. The influence of sediment recycling and basement composition on evolution of mudrock chemistry in the southwestern United States. Geochimica et Cosmochimica Acta, 59: 2919-2940.

Cullers, R.L., 1994. The controls on the major and trace element variation of shales, siltstones, and sandstones of Pennsylvanian-Permian age from uplifted continental blocks in Colorado to platform sediments in Kansas, USA. Geochimica et Cosmochimica Acta, 58: 4955-4972.

Czarnocki, J., 1919. Stratygrafia i tektonika Gór Świętokrzyskich (in Polish). Prace Towarzystwa Naukowego Warszawskiego, 28 $1-172$.

Czarnocki, J., 1923. Zechstein dans les Montagnes de Święty Krzyż (in Polish with French summary). Sprawozdanie Państwowego Instytutu Geologicznego, 2: 151-191.

Czarnocki, J., 1936. Überblick der Stratigraphie und Paläogeographie des Unterdevons im Polnischen Mittelgebirge (in Polish with German summary). Sprawozdanie Państwowego Instytutu Geologicznego, 8: 1-27.

Czarnocki, J., 1950. Geology of the Łysa Góra region (Święty Krzyż Mountains) in connection with the problem of iron ores at Rudki (in Polish with English summary). Prace Państwowego Instytutu Geologicznego, 1: 1-404.

Dadlez, R., 2001. Holy Cross Mts. area - Crustal structure, geophysical data and general geology. Geological Quarterly, 45 (2): 99-106.

Deczkowski, Z., Tomczyk, H., 1969. Stratigraphy of the older Palaeozoic in the Wilków borehole in the northern part of the Góry Świętokrzyskie (in Polish with English summary). Kwartalnik Geologiczny, 13 (1): 15-23.

Dickinson, W.R., 1970. Interpreting detrital modes of greywacke and arkose. Journal Sedimentary Petrology, 40: 695-707.

Dickinson, W.R., 1985. Interpreting provenance relations from detrital modes of sandstones. In: Provenance of Arenites (ed. G.G. Zuffa): 333-361. D. Reidel Publishing Company, Dordrecht-Boston.

Dickinson, W.R., Beard, L.S., Brakenbridge, G.R., Erjavec, J.L., Ferguson, R.C., Inman, K.F., Knepp, R.A., Lindberg, F.A., Ryberg, P.T., 1983. Provenance of North American Phanerozoic sandstones in relation to tectonic setting. GSA Bulletin, 94: 222-235.

Dorsey, R.J., 1985. Petrography of Neogene sandstones from the Coastal Range of eastern Taiwan: response to arc-continent collision. Petroleum Geology of Taiwan, 21: 187-215.

Dorsey, R.J., 1988. Provenance evolution and unroofing history of a modern arc-continent collision; evidence from petrography of Plio-Pleistocene sandstones, eastern Taiwan. Journal of Sedimentary Petrology, 58: 208-218.

Dzik, J., Pisera, A., 1994. The Mójcza Limestone and its sedimentation. Palaeontologia Polonica, 53: 5-41.

Eynatten, H.V., von, Barceló-Vidal, C., Pawlowsky-Glahn, V., 2003. Composition and discrimination of sandstones: a statisti- 
cal evaluation of different analytical methods. Journal of Sedimentary Research, 73: 47-57.

Fedo, C.M., Nesbitt, H.W., Young, G.M., 1995. Unravelling of effects of potassium metasomatosis in sedimentary rocks and paleosols, with implications for paleoweathering conditions and provenance. Geology, 23: 921-924.

Feng, R., Kerrich, R., 1990. Geochemistry of fine-grained clastic sediments in the Archean Abitibi greenstone belt, Canada. Implications for provenance and tectonic setting. Geochimica et Cosmochimica Acta, 54: 1061-1081.

Floyd, P.A., Leveridge, B.E., 1987. Tectonic environment of the Devonian mode and geochemical evidence from turbiditic sandstones. Journal of Geological Society, 144: 531-542.

Floyd, P.A., Winchester, J.A., Park, R.G., 1989. Geochemistry and tectonic setting of Lewisian clastic metasediments from the early Proterozoic Loch Maree Group of Gairloch, N.W. Scotland. Precambrian Research, 32: 97-131.

Floyd, P.A., Shail, R., Leveridge, B.E., Franke, W., 1991. Geochemistry and provenance of Rhenohercynian synorogenic sandstones: implications for tectonic environment discrimination. Geological Society Special Publications, 57: 173-188.

Gazzi, P., 1966. Le arenarie del flysch sopracretaceo dell'Appennino modenese; correlazioni con il flysch di Monglhidoro (in Italian). Mineralogia e Petrografica Acta, 12: 69-97.

Giese, U., Walter, R., Katzung, G., 1994. Detrital composition of Ordovician sandstones from the Rügen boreholes: implications for the evolution of the Tornquist Ocean. Geologische Rundschau, 83: 293-308.

Girty, G.H., Ridge, D.L., Knaack, C., Johnson, D., Al-Riyami, R.K., 1996. Provenance and depositional setting of Paleozoic chert and argillite, Sierra Nevada, California. Journal of Sedimentary Research, 66: 107-118.

Heier, K.S., Billings, G.K., 1970. Rubidium. In: Handbook of Geochemistry (ed. K.H. Wedepohl). Springer, Berlin/Heidelberg.

Herron, M.M., 1988. Geochemical classification of terrigenous sands and shales from core or log data. Journal of Sedimentary Petrology, 58: 820-829.

Hong, E., 1997. Evolution of Pliocene to Pleistocene sedimentary environments in an arc-continent collision zone: evidence from analysis of lithofacies and ichnofacies in the south - western foothills of Taiwan. Journal of Asian Earth Sciences, 15: 381-392.

Huang, C.Y., Wu, W.Y., Chang, C.P., Tsao, S., Yuan, P.B., Lin, C.W., Xia, K.Y., 1997. Tectonic evolution of accretionary prism in the arc-continent collision terrane of Taiwan. Tectonophysics, 281: 31-51.

Huang, C.Y., Yuan, P.B., Lin, C.W., Wang, T.K., Chang, C.P., 2000 Geodynamic processes of Taiwan arc-continent collision and comparison with analogs in Timor, Papua New Guinea, Urals and Corsica. Tectonophysics, 325: 1-21.

Ingersoll, R.V., Bullard, T.F., Ford, R.L., Grim, J.P., Pickle, J.D., Sares, S.W., 1984. The effect of grain size on detrital modes: a test of the Gazzi-Dickinson point-counting method. Journal of Sedimentary Petrology, 54: 103-116.

Janik, T., Grad, M., Guterch, A., Dadlez, R., Yliniemi, J., Tiira, T., Keller, G.R., Gaczyński, E., Środa, P., Komminaho, K., Hrubcova, P., Czuba, W., Malinowski, M., 2005. Lithospheric structure of the Trans-European Suture Zone along the TTZ-CEL03 seismic transect (from NW to SE Poland). Tectonophysics, 411: 129-156.

Jaworowski, K., 1971. Sedimentary structures of the Upper Silurian siltstones in the Polish Lowlands. Acta Geologica Polonica, 21: 519-571.

Jaworowski, K., 2000. Facies analysis of the Silurian shale-siltstone succession in Pomerania (northern Poland). Geological Quarterly, 44: 297-315.

Jaworowski, K., Sikorska, M., 2006. Łysogóry Unit (Central Poland) versus East European Craton - application of sedimentological data from Cambrian siliciclastic association. Geological Quarterly, 50 (1): 77-88.
Johnson, M.E., 2006. Relationship of Silurian sea-level fluctuations to oceanic episodes and events. GFF, 128: 115-121.

Kamp, P.C., van de, Leake, B. E., 1995. Petrology and geochemistry of siliciclastic rocks of mixed feldspathic and ophiolitic provenance in the Northern Apennines, Italy. Chemical Geology, 122: $1-20$.

Katzung, G., 2001. The Caledonides at the southern margin of the East European Craton. Neues Jahrbuch für Geologie und Paläontologie Abhandlungen, 222: 3-53.

Konon, A., 2007. Strike-slip faulting in the Kielce Unit, Holy Cross Mountains, central Poland. Acta Geologica Polonica, 57: 415-441.

Kowalczewski, Z., 1974. Geological and structural aspects of magmatism in the Góry Świętokrzyskie Mts. against the background of recent research (in Polish with English summary). Biuletyn Instytutu Geologicznego, 275: 11-62.

Kowalczewski, Z., Lisik, R., 1974. New data on diabases and geological structure of the Pragowiec area in the Góry Świętokrzyskie Mts. (in Polish with English summary). Biuletyn Instytutu Geologicznego, 275: 113-158.

Kozłowski, W., 2003. Age, sedimentary environment and palaeogeographical position of the Upper Silurian oolitic beds in the Holy Cross Mountains (Central Poland). Acta Geologica Polonica, 53: 341-357.

Kozłowski, W., 2008. Lithostratigraphy and regional significance of the Nowa Słupia Group (Upper Silurian) of the Łysogóry region (Holy Cross Mountains, Central Poland). Acta Geologica Polonica, 58: 43-74.

Kozłowski, W., Munnecke, A., 2010. Stable carbon isotope development and sea-level changes during the Late Ludlow (Silurian) of the Łysogóry region (Rzepin section, Holy Cross Mountains, Poland). Facies, 56: 615-633.

Kozłowski, W., Tomczykowa, E., 1999. A new occurrence of benthic fauna in the Niewachlów Greywackes (Upper Silurian) from Zalesie near Łagów in the Holy Cross Mountains. Geological Quarterly, 43 (1): 129-134.

Kozłowski, W., Domańska, J., Nawrocki, J., Pecskay, Z., 2004. The provenance of the Upper Silurian greywackes from the Holy Cross Mountains (Central Poland). Mineralogical Society of Poland, Special Papers, 24: 251-254.

Krzemiński, L., 2004. Geochemical constraints on the origin of the mid-Palaeozoic diabases from the Holy Cross Mts. and Upper Silesia, southeastern Poland. Geological Quarterly, 48 (2): 147-158.

Krzemiński, L., Poprawa, P., 2006. Geochemistry of the Ordovician and Silurian clastic sediments of the Koszalin-Chojnice zone and the western Baltic Basin (N Poland) (in Polish with English summary). Prace Państwowego Instytutu Geologicznego, 186: 123-148.

Langier-Kuźniarowa, A., Ryka, W., 1972. Silurian bentonites of the Góry Świętokrzyskie Mountains (in Polish with English summary). Biuletyn Instytutu Geologicznego, 261: 7-30.

Lester, R., Lavier, L.L., McIntosh, K., Van Avendonk, H.J., Wu, F., 2012. Active extension in Taiwan's pre-collision zone: A new model of plate bending in continental crust. Geology, 40: 831-834.

Lin, A.T., Watts, A.B., 2002. Origin of the West Taiwan basin by orogenic loading and flexure of a rifted continental margin. Journal of Geophysical Research, 107 (B9): 2185.

Malec, J., 2001. Sedimentology of deposits around the Late Caledonian unconformity in the western Holy Cross Mountains. Geological Quarterly, 45 (4): 397- 415.

Masiak, M., Podhalańska, T., Stępień-Sałek, M., 2003. Ordovician-Silurian boundary in the Bardo Syncline, Holy Cross Mountains, Poland - new data on fossil assemblages and sedimentary succession. Geological Quarterly, 47 (4): 311-330.

McLennan, S.M., 1989. Rare earth elements in sedimentary rocks: Influence of provenance and sedimentary processes. Reviews in Mineralogy, 21: 169-200. 
McLennan, S.M., 2001. Relationships between the trace element composition of sedimentary rocks and upper continental crust. Geochemistry, Geophysics, Geosystems, 2: 2000GC000109.

McLennan, S.M., Hemming, S., McDaniel, D.K., Hanson, G.N., 1993. Geochemical approaches to sedimentation, provenance and tectonics. GSA Special Paper, 284: 21-40.

Narkiewicz, M., 2002. Ordovician through earliest Devonian development of the Holy Cross Mts. (Poland): Constraints from subsidence analysis and thermal maturity data. Geological Quarterly, 46 (3): 255-266.

Narkiewicz, M., Resak, M., Littke, R., Marynowski, L., 2010. New constraints on the Middle Palaeozoic to Cenozoic burial and thermal history of the Holy Cross Mts. (Central Poland): results from numerical modelling. Geologica Acta, 8: 189-205.

Narkiewicz, M., Grad, M., Guterch, A., Janik, T., 2011. Crusta seismic velocity structure of southern Poland: Preserved memory of a pre-Devonian terrane accretion at the East European Platform margin. Geological Magazine, 148: 191-210.

Nawrocki, J., 2000. Late Silurian paleomagnetic pole from the Holy Cross Mountains: Constraints for the post-Caledonian tectonic activity of the Trans-European Suture Zone. Earth and Planetary Science Letters, 179: 325-334

Nawrocki, J., Poprawa, P., 2006. Development of Trans-European Suture Zone in Poland: From Ediacaran rifting to Early Palaeozoic accretion. Geological Quarterly, 50 (1): 59-76.

Nawrocki, J., Dunlap, J., Pecskay, Z., Krzemiński, L., Żylińska A., Fanning, M., Kozłowski, W., Salwa, S., Szczepaniak, Z., Trela, W., 2007. Late Neoproterozoic to Early Palaeozoic palaeogeography of the Holy Cross Mountains (Central Europe): An integrated approach. Journal of Geological Society, 164: 405-423.

Nawrocki, J., Salwa, S., Pańczyk, M., 2013. New ${ }^{40} \mathrm{Ar}-{ }^{39} \mathrm{Ar}$ age constrains for magmatic and hydrothermal activity in the Holy Cross Mts. (southern Poland). Geological Quarterly, 57 (3): 551-560.

Nesbitt, H.W., Young, G.M., 1982. Early Proterozoic climates and plate motions inferred from major element chemistry of lutite. Nature, 299: 715-717.

Nesbitt, H.W., Young, G.M., 1984. Prediction of some weathering trends of plutonic and volcanic rocks based on thermodynamic and kinetic considerations. Geochimica et Cosmochimica Acta, 48: $1523-1534$

Nesbitt, H.W., Fedo, C.M., Young, G.G., 1997. Quartz and feldspar stability, steady and non-steady-state weathering, and petrogenesis of siliciclastic sands and muds: Journal of Geology, 105: 173-191.

Oczlon M.S., Seghedi A., Carrigan, C.W., 2007. Avalonian and Baltican terranes in the Moesian Platform (southern Europe Romania, and Bulgaria) in the context of Caledonian terranes along the southwestern margin of the East European craton. GSA Special Paper, 423: 375-400.

Pettijohn, F.J., Potter, P.E., Siever, R., 1972. Sand and Sandstone. Springer-Verlag, New York.

Pettijohn, F.J., Potter, P.E., Siever, R., 1987. Sand and Sandstone, Second Edition. Springer-Verlag, Berlin.

Pharaoh, T.C., 1999. Palaeozoic terranes and their lithospheric boundaries within the Trans-European Suture Zone (TESZ): a review. Tectonophysics, 314: 17-41.

Podhalańska, T., Modliński, Z., 2006. Stratigraphy and facies characteristics of the Ordovician and Silurian deposits of the Koszalin-Chojnice zone; similarities and differences to the western margin of the East European Craton and Rügen area (in Polish with English summary). Prace Państwowego Instytutu Geologicznego, 186: 39-78.

Poprawa, P., 2006. Development of the Caledonian collision zone along the western margin of Baltica and its relation to the foreland basin (in Polish with English summary). Prace Państwowego Instytutu Geologicznego, 186: 189-214.

Poprawa, P., Sliaupa, S., Stephenson, R., Lazauskiene, J., 1999. Late Vendian-Early Palaeozoic tectonic evolution of the Baltic
Basin: Regional tectonic implications from subsidence analysis. Tectonophysics, 314: 219-239.

Poprawa, P., Paszkowski, M., Fanning, M.C., Pecskay, Z., Nawrocki, J., Sikorska, M., 2006. Geochronological characteristics of source areas for the Lower Palaeozoic sediments from the NW East European Craton and Koszalin-Chojnice zone; dating of detrital mica (K/Ar) and zircon (U/Pb SHRIMP). Prace Państwowego Instytutu Geologicznego, 186: 149-164.

Pożaryski, W., Tomczyk, H., 1993. Geological cross-section through SE Poland (in Polish with English summary). Przeglad Geologiczny, 41: 687-695.

Przybyłowicz, T., Stupnicka, E., 1991. Manifestation of volcanism in Ordovician and Silurian of the southern part of Świętokrzyskie Mts. Archiwum Mineralogiczne, 46: 137-153.

Purevjav, N., Roser, B., 2012. Geochemistry of Devonian-Carboniferous clastic sediments of the Tsetserleg terrane, Hangay $\mathrm{Ba}$ sin, Central Mongolia: Provenance, source weathering, and tectonic setting. Island Arc, 21: 270-287.

Romanek, A., Rup, M., 1989. Greywackes from Jurkowice and the Upper Silurian greywacke series in the southern part of the Góry Świętokrzyskie Mts (in Polish with English summary). Biuletyn Państwowego Instytutu Geologicznego, 362: 41-64.

Roser, B.P., 2000. Whole-rock geochemical studies of clastic sedimentary rocks. Memoirs of the Geological Society of Japan, 57: 73-89.

Roser, B.P., Korsch, R.J., 1986. Determination of tectonic setting of sandstone mudstone suites using $\mathrm{SiO}_{2}$ content and $\mathrm{K}_{2} \mathrm{O}$ $/ \mathrm{Na}_{2} \mathrm{O}$ ratio. Journal of Geology, 94: 635-650.

Roser, B.P., Korsch, R.J., 1988. Provenance signatures of sandstone-mudstone suites determined using discrimination function analysis of major element data. Chemical Geology, 67: 119-139

Roy, P.D., Caballero, M., Lozano, R., Smykatz-Kloss, W., 2008 Geochemistry of late quaternary sediments from Tecocomulco lake, central Mexico: implication to chemical weathering and provenance Chem. Chemie der Erde - Geochemistry, 68: 383-393.

Ryka, W., Tomczyk, H., 1959. Bentonites in Old Palaeozoic sediments from the Święty Krzyż Mts. (in Polish with English summary). Kwartalnik Geologiczny, 3 (4): 710-712.

Samsonowicz, J., 1934. Explication de la feuille Opatów. Carte Géologique Générale de la Pologne au 100 000. Varsovie.

Schatz, M., Zwing, A., Tait, J., Belka, Z., Soffel, H.C., Bachtadse, V., 2006. Paleomagnetism of Ordovician carbonate rocks from Malopolska Massif, Holy Cross Mountains, SE Poland magnetostratigraphic and geotectonic implications. Earth and Planetary Science Letters, 244: 349-360.

Schovsbo, N.H., 2003. The geochemistry of Lower Palaeozoic sediments deposited on the margins of Baltica. Bulletin of the Geological Society of Denmark, 50: 11-27.

Semenenko, N.P., 1968. Riphean volcanism and mineralization of the western part of the Ukrainian Shield (in Russian with English summary). Naukova Dumka, Kiev.

Shaw, D.M., 1968. A review of K-Rb fractionation trends by covariance analysis. Geochimica et Cosmochimica Acta, 32: $573-602$

Stempień, M., 1990. Ordovician and Silurian acritarchs of the Niestachów sandstone formation. Annales Societatis Geologorum Poloniae, 60: 59-74.

Szulczewski, M., 1995. Depositional evolution of the Holy Cross Mts. (Poland) in the Devonian and Carboniferous - a review. Geological Quarterly, 39 (4): 471-488.

Szulczewski, M., 1996. Outline of the Holy Cross Mountains geology. In: Sixth European Conodont Symposium, Excursion Guide (eds. M. Szulczewski and S. Skompski): 21-27. Instytut Paleobiologii PAN, Warszawa.

Taylor, S.R., McLennan, S.M., 1985. The Continental Crust: Its Composition and Evolution. Blackwell Scientific, Oxford.

Tomczyk, H., 1954. Stratigraphy of the Gothlandian in the Międzygórz basin - Święty Krzyż Mts. on the basis of the fauna 
from graptolitic shales (in Polish with English summary). Biuletyn Instytutu Geologicznego, 93: 1-66.

Tomczyk, H., 1956. Wenlock and Ludlow in the Kielce Syncline of the Holy Cross Mts. (in Polish with English summary). Prace Instytutu Geologicznego, 16.

Tomczyk, H., 1970. Silurian. In: Stratigraphy - Precambrian and Palaeozoic. Geology of Poland 1, part 1 (eds. S. Sokołowski, S. Cieśliński and J. Czermiński): 237-319. Wyd. Geol., Warszawa.

Tomczyk, H., 1974. Góry Świętokrzyskie. In: Budowa geologiczna Polski, Tektonika (ed. W. Pożaryski): 128-197. Wyd. Geol., Warszawa.

Tomczyk H., 1987. Korelacja tektoniczno-strukturalna brzegu platformy wschodnioeuropejskiej z regionem Świętokrzyskim (epoka kaledońsko-waryscyjska) (in Polish). Kwartalnik Geologiczny, 31 (2-3): 486-488.

Tomczyk, H., Tomczykowa, E., 1976. Development of Ashgill and Llandovery sediments in Poland. In: The Ordovician System: proceedings of a Palaeontological Association symposium, Birmingham, September 1974 (ed. M.G. Bassett): 327-348. University of Wales Press and National Museum of Wales, Cardiff.

Tomczykowa, E., 1993. Upper Ludlow trilobites from the southern part of the Holy Cross Mts. Geological Quarterly, 37 (3): 359-384.

Tomczykowa, E., Tomczyk, H., 2000. The lower Palaeozoic in the Daromin IG 1 borehole - confirmation of the concept of the terrane structure of the Łysogóry and Małopolska blocks (Góry Świętokrzyskie Mts.) (in Polish with English summary). Biuletyn Państwowego Instytutu Geologicznego, 393: 167-203.

Torsvik, T.H., Rehnstrom, E.F., 2003. The Tornquist Sea and the Baltica-Avalonia docking. Tectonophysics, 362: 67-82.

Torsvik, T.H., Smethurst, M.A., Meert, J.G., Voo, R., van der, McKerrow, W.S., Brasier, M.D., Sturt, B.A., Walderhaug, H.J., 1996. Continental break-up and collision in the Neoproterozoic and Palaeozoic - a tale of Baltica and Laurentia. Earth-Science Reviews, 40: 229-258.
Totten, M., Hanan, M., Weaver, B., 2000. Beyond whole-rock geochemistry of shales: The importance of assessing mineralogical controls for revealing tectonic discriminants of multiple sediment sources for the Ouachita Mountain flysch deposits. GSA Bulletin, 112: 1012-1022.

Trela, W., 1998. Sedimentary environment of the condensed Ordovician limestones from Mójcza section (Holy Cross Mts.). Geological Quarterly, 42 (3): 289-300.

Winchester, J.A., Floyd, P.A., Crowley, Q.G., Piasecki, M.A.J., Lee, M.K., Pharaoh, T.C., Williamson, P., Banka, D., Verniers, J., Samuelsson, J., Bayer, U., Marotta, A.-M.,Lamarche, J., Franke, W., Dorr, W., Valverde-Vaquero, P., Giese, U., Vecoli, M., Thybo, H., Laigle, M., Scheck, M., Maluski, H., Marheine, D., Noble, S.R., Paarish, R.R., Evans, J., Timmerman, H., Gerdes, A., Guterch, A., Grad, M., Cwojdzinski, S., Cymerman, Z., Kozdroj, W., Kryza, R., Aleksandrowski, P., Mazur, S., Stedra, V., Kotkova, J., Belka, Z., Patocka, F., Kachlik, V., 2002. Palaeozoic amalgamation of Central Europe: New results from recent geological and geophysical investigations. Tectonophysics, 360: 5-21.

Winchester, J.A., Pharaoh, T.C., Verniers, J., loane, D., Seghedi, A., 2006. Palaeozoic accretion of Gondwana-derived terranes to the East European Craton: Recognition of detached terrane fragments dispersed after collision with promontories. Geological Society Memoir, 32: 323-332.

Znosko, J., 1974. Outline of the tectonics of Poland and the problems of the Vistulicum and Variscicum against the tectonics of Europe. Biuletyn Instytutu Geologicznego, 274: 7-38.

Żelaźniewicz, A., Buła, Z., Fanning, M., Seghedi, A., Żaba, J., 2009. More evidence on Neoproterozoic terranes in Southern Poland and southeastern Romania. Geological Quarterly, 53 (1): 93-124.

Żylińska, A., 2002. Stratigraphic and biogeographic significance of Late Cambrian trilobites from Łysogóry (Holy Cross Mountains, central Poland). Acta Geologica Polonica, 52: 217-238. 